\title{
DELEGATING AUTHORITY TO THE COMMUNITY OF SCHOLARS
}

D. BROCK HORNBY*

\section{OUTLINE}

I. INTRODUCTION

II. Legal Principles Regarding Structures: AN Overview
A. Delegation
B. Subdelegation

III. Formal Governance Structures in Public Higher Education
A. Institutional Authority
B. Centralized Authority
C. Special-Purpose Authority

IV. Application of Legal Principles Regarding Structures to Higher Education

A. Delegation in Higher Education

(1) Tendency Toward Recognition of Broad Delegations

(2) Permissibility of Delegations

B. Subdelegation in Higher Education

(1) Recognition of Subdelegations

(2) Permissibility of Subdelegations

V. ApPropriateness of the AdMinistrative LAW MODEI
A. Unique Historical Traditions
B. Academic Freedom
C. Campus as "Community"
D. Higher Bducation as State-Owned Enterprise
E. Private, Foundation, and Federal Financial Support
F. Governance by Trustees

VI." Sumamary and Application

A. General Conclusions

B. A Case in Point

(1) Recognition of the Subdelegation

(2) Permissibility of the Subdelegation

* Member, Maine and Virginia Bars; Associate Professor of Law, University of Virginia School of Law, 1970-74; B.A. 1965, University of Western Ontario; J.D. 1969, Harvard University. The author wishes to thank Everette L. Doffermyre, J.D. 1973, University of Virginia, Member, Georgia Bar, and James R. Henderson IV, J.D. 1974, University of Virginia, Member, District of Columbia and Virginia Bars, for their important contributions to this Article.

THE FOLLOWING CITATIONS WILL BE USED IN THIS ARTICLE:

Carnegie Commission on Higher Education, Governance of Higher EducaTION (C. Kerr ed. 1973) [hereinafter cited as KeRR REPORT]; 


\section{INTRODUCTION}

In December, 1971, Brenda Page Bright, a student at Mary Washington College in Fredericksburg, Virginia, was accused of stealing money from a fellow student. In accordance with established college procedures, she was tried before the Student Honor Council, a committee of popularly elected students charged with administering the school's honor system. The Honor Council found her guilty as charged and permanently dismissed her from the college. No appeal was available from an Honor Council decision, either to the Board of Visitors or to any faculty or administrative personnel.

Ms. Bright thereupon instituted an action in federal court ${ }^{1}$ challenging her expulsion on two grounds: first, the traditional argument in current student litigation, that she had not been accorded due process in the expulsion proceedings; and second, a more novel tack for student litigation, that the Board of Visitors of Mary Washington College had unlawfully delegated its disciplinary authority to the Student Honor Council. This second contention concerning the location of the power was the nub of the lawsuit. Specifically, Ms. Briglit argued that the Virginia legislature had, by statute, entrusted the Board of Visitors with responsibility "to regulate the government and discipline of the students "2 The Board, she contended, could not abrogate this responsibility by transferring a significant portion of its disciplinary authority to a private group of students not subject to either immediate or indirect control by the state legislature. ${ }^{3}$ In 1973 , Ms. Rhonda Robertson at-

Carnegie Commission on Higher Education, The University as an OrganizaTION (J. Perkins ed. 1973) [hereinafter cited as PERKINS REPORT];

K. Davis, Administrative LaW Treatise (1958) [hereinafter cited as K. Davis];

K. Davis, Administrattve Law Treatise (Supp. 1970) [hereinafter cited as K. Davis (Supp. 1970)];

U.S. Dep't of Health, Educ. \& Welfare, Office of Educ., Report on Higher EDUCATTON (1971) [hereinafter cited as NEWMAN REPORT].

1. Bright v. Rector \& Visitors, Civil No. 438-72-R (B.D. Va., filed Aug. 28, 1972).

2. VA. Code ANN. $\S \S 23-76,23-88$ (1950), as amended, $\S \S 23-76,23-91.40$ (Repl. vol. 1973). At the time Ms. Bright was expelled, the Board of Visitors of the University of Virginia had responsibility for Mary Washington College. Section 23-88 has since been repealed, and in its place section $23-91.40$ has been enacted, providing for a separate Board of Visitors for Mary Washington.

3. Paragraph 5 of the complaint alleged that the Board of Visitors of Mary Washington

in total violation of its delegated authority from the State Legislature, has further delegated a portion of its authority, responsibility and control, i.e. regarding student discipline and regulation of student behavior, to the Student Honor Council, a private organization totally outside the control or supervision of the Defendant or the Legislature. Complaint, $\pi 5$, in Bright v. Rector \& Visitors, Civil No. 438-72-R (E.D. Va., filed Aug. 28, 1972). 
tacked the University of Virginia honor system on identical grounds. ${ }^{4}$ Since both suits were filed in federal court, each was dismissed for lack of a substantial federal question. ${ }^{5}$ But the atypical issue raised by these two cases is by no means spurious and deserves careful analysis.

If there is nerit in a delegation argument like Ms. Bright's and Ms. Robertson's, its significance ranges beyond the particular disciplinary arrangements at Mary Washington College and at the University of Virginia. Most state imstitutions of higher education are formally structured in the same fashion as these two: general authority is placed by statute in the hands of a board of trustees popularly elected ${ }^{b}$ or chosen by the state legislature or governor. ${ }^{7}$ Yet, as at these two institutions, many boards of trustees do not actively exercise all the power that is theirs. ${ }^{8}$ Faculty, students, and administrators "share" varying portions of that power. ${ }^{9}$ Since these subdelegations of power have resulted largely from governing board acquiescence, not from revision of statutory structures by state legislatures, ${ }^{10}$ a challenge to the governing boards' authority to make this subdelegation of power is a challenge

4. Robertson v. Rector \& Visitors, Civil No. 73-C-22-C (W.D. Va., filed July 23, 1973).

5. The subdelegation issue, essentially a matter of statutory construction, see text accompanying notes $42-45$ infra, is a question of state law.

6. E.g., IllinoIs ANN. Stat. ch. 144, \$ 41 (Smith-Hurd 1964).

7. E.g., Alaska Stat. $\$ 14.40 .150$ (1971) (appointment by the governor subject to confirmation by the legislature).

8. McGrath, Who Should Have the Power?, in POWER \& AUTHORITY 187, 188-89 (H. Hodgkinson \& L. Meeth eds. 1971).

9. See generally E. McGrath, Should Students Share the Power? A Study of Them Role In College and Untversity Governance (1970); American Association of University Professors et al., 1966 Statement on Government of Colleges and Universities, in ACADEMIC FreEdom and TENURE 90 (L. Joughin ed. 1967). It is said that this "basic doctrine" is accepted by virtually all writers on university government. H. MASON, COLlEgE AND UNIVERSITY GOVERNMENT XIII (1972). Empirical investigation produces a more skeptical view of the practice. See J. BaLdRIDGE, ACADEMrC Governance: Research on Institutional Polttics and Decision Making 8-9 (1971).

10. See C. Jencrs \& D. Riesman, The ACAdemic Revolution 16 (1968):

College professors have not for the most part won significant formal power, either individually or collectively, over the institutions that employ them ..... Departments, too, have little formal power except sometimes over conrse offerings and requirements .... Ultimate control mostly remains where it has always been-with the administration, the lay trustees, and in some cases the legislature.

The trustees, however, are seldom what they once were . . . If there is strong internal pressure for a given course of action, they are likely to go along. They are also more likely than they once were to delegate authority to the college administration, either de jure or de facto.

Cf. C. OTTEN, UNIVERSITY AUTHORITY AND THE STUDENT 203 (1970), quoting California Governor Ronald Reagan in 1968: "I suggest that it is time for these Boards [of Regents] to reassess their own goals, their patteru of only reacting to crises meeting by meeting, and the degree to which they have delegated away responsibility and abandoned principle." 
to the legality of much of contemporary college and university governance. Indeed, the manner in which such power has been acquired from the board-often by de facto assumption rather than by formal grant $^{11}$-might be a potential source of legal controversy in many institutions were a case like Bright or Robertson to challenge an action taken by a student or faculty organization on the ground that the governing board itself had never delegated such power. ${ }^{12}$ The challenge is not limited to student disciplinary arrangements. Allocations of funds and recognition of organizations by student or faculty councils are equally subject to attack. Actions taken by faculty grievance or tenure committees could likewise be challenged if such actions were not grounded on formal and authorized grants of authority.

A separate development in college and umiversity governance also raises potential legal problems concerning the extent of power granted to the governing body. Concurrent with the trend toward greater student and faculty participation in governance, state legislatures lave moved toward greater centralized authority over all public (and soinetimes private) higher education within a state. ${ }^{13}$ The difficulty in articulating precise standards to guide statewide boards in planning, co-

\section{See Kerr Report 16:}

Some campuses have a Kafkaesque character-an uncertainty about who can make what decisions and on what grounds. Who are the judges? Where is the "Castle"? It is important to clarify who has what authority and what policies are to be followed, and to set forth for all to see where answers can be obtained. An effective administration is better than a confusing anarchy.

12. Collective bargaining may be intensifying recognition of this phenomenon as faculties find themselves bargaining for power they had formerly exercised informally. Administrations are increasingly seeking to add "management rights" clauses to collective bargaining agreements. Semas, Administrations Get Tougher in Bargaining with Faculties; Some Negotiations Slowed, The Chronicle of Higher Education, July 2, 1973, at 1 , col. 3 .

13. See generally Harris, Statewide Coordinating Agencies for Higher Education: A Brief Overview, in U.S. Department of HEW, State Departments of Education, State Boards of Education, and Chief State School Officers 97 (1973); Kerr REPORT 1: "The greatest shift of power in recent years has taken place not inside the campus, but in the transfer of authority froin the canpus to outside agencies." This development has not always paid close attention to existing legal structures. See State Bd. of Educ. v. State Bd. of Higher Educ., 29 Utah 2d 110, 112, 505 P.2d 1193, 1194 (1973) (upholding legislative grant of authority to state board of higher education, despite constitutional provision that state board of education shall control the public school system, constitutionally defined to include "an agricultural college; a university; and such other schools as the Legislature may establish").

In light of the trend toward greater centralized authority over higher education, some commentators say that the days of campus autonomy are numbered. E.g., Mayhew, American Higher Education Now and in the Future, 404 THE ANNals 44, 51-52, 55 (1972). Other observers call for resistance to the trend. See generally CARNEGre Commission on Higher Education, The Capitol and the Campus (1971); Newman REPORT 71-74. 
ordinating, and operating complex systems of higher education, together with the impossibility of definitively projecting future educational needs and resolving conflicting political demands, has produced legislation that assigns power with standards ambiguous at best. A conventional legal argument calls authority delegated without adequate standards an unlawful avoidance by a legislature of its responsibility to legislate. ${ }^{14}$

Legal concern for the exercise of decision-making authority at the proper level derives from a traditional administrative law analysis apphied to government agencies generally. As yet, the appropriateness of this analysis to public higher education has not been finally resolved in court decisions or legal commentary. The htigation that heretofore has surrounded public colleges and universities has been mostly of constitutional dimensions, ${ }^{15}$ focusing on the procedures by which decisions are made and, to a lesser extent, their substantive correctness, but not touching upon the administrative law question of at what levels of authority decisions should be made. The model used in resolving the procedural issues, however, has been largely the conventional administrative law model. Now, legal commentators ${ }^{16}$ and, increasingly, legislators $^{17}$ are applying this treatment to public higher education in a vari-

14. See text accompanying notes 21-41 infra. At a minimum, legal and political conflict between institutions and the centralized board can be predicted. See, e.g., Regents of Univ. of Mich. v. State, 47 Mich. App. 23, 208 N.W.2d 871 (1973); L. GLENNY \& T. Dalglish, Public Universities, State Agencies, and the Law: Constitutional Autonomy IN DecLine 138 (1973); Symposium, The Politics of Public Higher Education, 59 A.A.U.P. BuLL. 286 (1973).

15. Litigation of constitutional dimensions has been prevalent since the landinark case of Dixon v. Alabama State Bd. of Educ., 294 F.2d 150 (5th Cir.), cert. denied, 368 U.S. 930 (1961). The issues raised most frequently in the constitutional litigation affecting colleges and universities have been (1) the first amendinent rights to freedom of speech, assembly, and association, often characterized in this context as "academic freedom," see, e.g., Healy v. James, 408 U.S. 169 (1972); and (2) fourteenth amendment procedural rights for the discipline of a student or faculty member, see, e.g., Board of Regents v. Roth, 408 U.S. 564 (1972). Colleges and universities also confront a good many other less highly publicized legal issues that parallel those faced by any modern corporation-tax, torts, contracts, trusts, and patents, to name only a few.

16. See, e.g., Comment, Enrollment Limitations on the Oregon State System of Higher Education, 1969-1971: Fact or Fiction?, 49 ORE. L. REv. 322 (1970).

17. See, e.g., WASH. REv. CODE ANN., APr. $\$ 28 B .19 .020$ (Supp. 1972) (administrative procedure act for higher education).

In the very recent case of Cathcart v. Andersen, 530 P.2d 313 (Wash. 1975), the Supreme Court of Washington determined that the faculty of the University of Washington School of Law was a "governing body" of a "public agency" within the meaning of the state's Open Public Meetings Act, 9 WASH. Rev. Code $\$ 42.30 .030$ (Supp. 1972). In so doing, the court appeared to regard this entity of public higher education as no different than any other administrative subagency. The court was careful to observe that goveruing authority had been explicitly delegated by statute to the University's 
ety of contexts. On the other hand, most educators writing on public higher education have maintained that its structure is unique and not amenable to assumptions applied to governmental agencies-the conventional focus of administrative law. ${ }^{18}$

This Article confronts the question of whether the analysis of conventional administrative law is appropriate for resolving legal disputes over the allocation of authority in public higher education. ${ }^{19}$ It will begin with a summary of the general legal principles that apply to assignments of governmental authority. Then the formal structure of authority in American public higher education will be outlined, and judicial application of the legal principles to this structure will be examined. This examination will reveal that the little case law on the subject has largely failed to confront the issue and might be construed as suggesting that higher education should be treated like any other state operation. Although public higher education is clearly an agency of state government, in many respects it is sui generis. This Article will examine some of the peculiar characteristics of higher education and will consider whether, and to what extent, legal problems regarding the governance of education should be resolved under the orthodox administrative law model. Fimally, for purposes of illustration, the Article will conclude with an analysis and proposed resolution of the specific problem adverted to above-the exercise of disciplinary authority by a student honor council.

board of regents and explicitly subdelegated to the law faculty, which exercised "considerable power over the governing of the school" and which had become the recipient of a "quasi-legislative authority." 530 P.2d at 316. Accordingly, the court held that the monthly meetings of the faculty must be open to the public under the Open Public Meetings Act.

18. Or, for that matter, the corporation model, the foundation model, or the civil community model. See generally J. Corson, Governance of Colleges and UNIVERSIties (1960); KerR ReporT; H. Mason, supra note 9; PERKINS Report 38-136. But cf. L. Epstein, Governing the University (1974) (discussed in note 124 infra). On the specific question of decision-making structures, for example, a classic treatment of college and university governance asserts that "[i]t is idle to say that all authority flows from the [governing] board." J. Corson, supra, at 57-58. Another concludes that "[t]he locus of power in colleges and universities is a complicated and somewhat obscure subject, which an analysis of the related legal documents is more likely to obfuscate than to illuminate." E. McGRATH, supra note 9, at 60-61.

19. The possible tension with legal requirenents has been noted elsewhere. E.g., W. Hull IV \& A. Shapiro, The UnIverisity Trustee In LAw aNd Practice (1973); Mager, Changes in Institutional Governance: Legal Restraints Involving Delegation of Authority by Governing Boards, in 5 The College Counsel; no. 1, at 37 (1970); Perkins, Organization Functions of the University, in PERRINs REPORT 3 ("The functions it must perform are not and cannot be discharged through the formal structure provided in its charter."). 


\section{Legal Principles Regarding Structures: An Overview}

Traditional administrative law analysis examines power at two different points: the initial grant of power from a legislature to an administrative officer or body (delegation) and the secondary grant of soine or all of that power by the administrative officer or body to subordinates (subdelegation). For the benefit of those unfamiliar with the development of the two legal doctrines, the following is a brief summary.

\section{A. Delegation $^{20}$}

An administrative agency or official is said to have no governmental power unless that power is assigned to it directly ${ }^{21}$ by constitution or by a body which itself derives power froin the constitution. Delegation, as a legal term, generally refers to a legislature's assignment of power (and function) to an administrative agency. ${ }^{22}$ As society has become more complex, it has become progressively more difficult for legislatures to make decisions on every question over which they have authority. Consequently, more and more power has been assigned to administrative agencies, and courts have become generous in recognizing delegated power in any agency.

The traditional legal concern with this practice related to separation of powers and legislative responsibility. ${ }^{23}$ As a famous treatise put it, "One of the settled maxims in constitutional law is, that the power conferred upon the legislature to make laws cannot be delegated to any other body or authority." ${ }^{4}$ Were the executive arm of government to undertake functions assigned to the legislature, the scheme of checks and balances would be cast askew. In addition to preserving the sepa-

20. Some will consider the subject of this Article a non-issue, having concluded that the outpouring of scholarly criticism has resulted in the death of delegation and subdelegation analysis. They would do well to read National Cable Television Ass'n v. United States, 94 S. Ct. 1146 (1974), and Federal Power Comm'n v. New England Power Co., 94 S. Ct. 1151 (1974), as well as the separate opinion of Justices Marshall and Brennan, concurring in part and dissenting in part to these decisions, id. at 1155. See also Wright, Book Review, 81 YALE L.J. 575 (1972). Finally, they should consider the treatment of delegation and subdelegation in state (as distinguished from federal) courts.

21. The assignment of power may be explicit or implicit. Cf. United States v. Nixon, 94 S. Ct. 3090, 3109 (1974).

22. See $1 \mathrm{~K}$. Davis $\$ 2.01$.

23. The limitation on the ability to delegate legislative power was advanced as a matter of both federal and state law. See generally $1 \mathrm{~K}$. Davis $\$ \S 2.01-.16 ; \mathrm{K}$. Davis $\$ \S 2.01-.16$ (Supp. 1970).

24. 1 T. Cooley, Constriutional Limitations 224 (8th ed. 1927). Conversely, it is said that the legislature cannot delegate what is essentially judicial power-for example, the authority to determine criminal guilt or innocence. See $1 \mathrm{~K}$. Davis $\$ 2.13$. 
ration of powers, the restriction was thought to serve an essentially democratic principle: certain decisions should be made by those responsible to the electorate. ${ }^{25}$ The assumption was that as decisions are made by agents one or more steps removed from the legislature, the electorate's influence is attenuated. Delegation of power to private parties rather than adininistrative officials has been viewed with particular suspicion. ${ }^{26}$

The consequent tension between the restraint on delegation in the interests of responsible government and the need for delegation in the interests of efficient government led to comproinise when the matter was pressed in the courts. Initially, the dilemma was resolved on the basis that although legislative power could not be delegated, administrators could be given the power to find facts upon which a legislative policy would be activated; alternatively, they could fill in the details of a general legislative deternination. ${ }^{27}$ These yet restrictive notions could not withstand the pressure for greater delegation, however, and courts adopted another formula, that power could be delegated as long as the legislature established standards for its exercise. ${ }^{28}$ Thus, for imtial grants of power the focus shifted to the adequacy of the legislative standards, the basic criterion being either an intelligible principle or standards as definite as reasonably practicable. ${ }^{29}$ Such limitations seem to have been particularly iniportant where the adjudication of individual interests, ${ }^{30}$ protected freedoms, or criminal sanctions ${ }^{31}$ occurred. Commentators observed, however, that despite the verbal deference to limitations on delegation, courts in practice seldom invalidated a delegation as a matter of federal law." Standards as vague as "public convenience" ${ }^{33}$ and "public interest" ${ }^{34}$ were deemed sufficient. As a matter of state law, on the other hand, while the exigencies of modern govern-

25. See L. JAFFE, Judicial Control of Administrative Action 33-34 (1965).

26. See $1 \mathrm{~K}$. DAvis $\$ 2.14 ; \mathrm{K}$. Davis $\S 2.14$ (Supp. 1970). This was particularly true "where power was given to private parties who were directly and personally interested in the result which they were supposed to determine." Rossiter v. Law Comm. of the State Bd. of Law Exammers, 42 U.S.L.W. 2017 (D. Colo. June 12, 1973).

27. $1 \mathrm{~K}$. Davis $\$ 2.02$, at 77 . These are sometimes identified as two separate stages. See, e.g., Note, Safeguards, Standards, and Necessity: Permissible Parameters for Legislative Delegations in Iowa, 58 Iowa L. REv. 974, 976-82 (1973).

28. Panama Refining Co. v. Ryan, 293 U.S. 388 (1935); see 1 K. Davis $\$ 2.03$.

29. American Power \& Light Co. v. SEO, 329 U.S. 90 (1946); see $1 \mathrm{~K}$. Davis $\S$ 2.04 .

30. $1 \mathrm{~K}$. DAvis $\S 2.10$.

31. United States v. Robel, 389 U.S. 258, 269-72 (1967) (Brennan, J., concurring).

32. 1 K. Davis $\$ \S 2.03-.05$; K. Davis $\$ \$ 2.03-.05$ (Supp. 1970).

33. See Federal Radio Comm'n v. Nelson Bros. Bd. \& Mortgage Co., 289 U.S. 266, 285 (1933).

34. See Nẹw Yộk Cenț. Șẹcs. Corp. v. United States, 287 U,S. 12, 24 (1932). 
ment led more and more courts to sustain delegations with only the vaguest of legislative standards, numerous state courts have adhered to a restrictive concept of delegation. ${ }^{35}$

The shift in focus from the early insistence that no legislative power could be delegated to the later search for adequate legislative standards has revealed another policy at stake within the delegation notion. The requirement of standards, if successfully imposed, could limit arbitrary action of officials or agencies by means of judicial review which would test the congruence of individual decisions with those standards. Professor Davis has advanced the view that restraint on arbitrary action could also be achieved without diminishing legislative efficiency by requiring the agency both to express standards where the legislature has failed to do so and to provide fair procedures for reaching decisions. ${ }^{30}$ Articulation of standards by the agency would at least provide a visible policy that the legislature could reject if it wished. ${ }^{37}$ Factors such as the importance of the subject inatter ${ }^{38}$ and the responsibility of the particular delegate ${ }^{39}$ would be relevant in assessing the standards and safeguards. Although a number of courts have adopted the Davis approach, ${ }^{40}$ some states still adhere to traditional delegation notions of legislatively adopted standards. ${ }^{41}$

\section{B. Subdelegation}

Subdelegation is the term used to distinguish secondary grants of authority to subordinates by an officer or board which has initially been

35. K. Davis $\$ 2.17$ (Supp. 1970). Professor Davis explains why problems of state delegation have a "different flavor":

Legislatures, especially in closing hours of a session, are often less responsible than Congress; their draftsmen are often less skillful in clarifying legislative intent; direct responsiveness to special-interest groups is often more pronounced; committee investigations are usually less thorough; delegations to petty officers is more common; and, especially, safeguards to protect against arbitrary action are generally less developed. $\mathbf{K}$. Davis, ADMINISTRATIVE LAW TEXr § 2.06, at 36-37 (1972).

For a comparison of one state's (Iowa) development with the federal development, see Note, supra note 27.

36. See generally K. Davis $\$ \S 2.00$ to $2.00-6$ (Supp. 1970); K. Davis, DiscretionARY JUSTICE 27-51 (1969).

37. Professor Davis suggests that courts could impose these requiremeuts through either the constitutional demand for due process when liberty or property is at stake or through a common law demand that delegation be permitted only when standards and safeguards are provided by the agency. $1 \mathrm{~K}$. DAvs $\$ 2.00-6$ (Supp. 1970).

38. Cf. $1 \mathrm{~K}$. Davis $\$ 2.10$, at 114.

39. Cf. id. $\S 2.07$, at 101 .

40. Id.; K. Davis $\$ 2.15$ (Supp. 1970). Iowa's position is described in detail in Note, supra note 27.

41. See, e.g., People v. Tibbitts, 56 Ill. 2d 56, 59, 305 N.E.2d 152, 155 (1973). 
delegated power. The legal question posed by the practice is, very simply, whether the legislature has accorded the official or board the power thus to subdelegate decisions. The principal issue is therefore one of statutory interpretation: ${ }^{42}$ does the statutory framework countenance the inaking of decisions by subordimates, or must the power be exercised exclusively by the board or officer named in the legislation? A statute that explicitly authorizes subdelegation of the authority ${ }^{43}$ effectively moots the issue as does a statute that explicitly precludes subdelegation. ${ }^{44}$ Litigation occurs when the mandate is unclear, generally because of legislative silence on the inatter. ${ }^{45}$

Litigated cases and legal commentary suggest that several factors may be important to deciphering legislative silence concerning subdelegation. Legislative history, of course, can be helpful where available. ${ }^{46}$ The legislative context may also be relevant. If a legislature normally provides explicitly for subdelegation, for example, failure to do so in a particular instance may prompt the inference that subdelegation is not permitted in that instance. ${ }^{47}$ On the other hand, a grant of a general rulemaking power is said to confer authority to subdelegate tasks unless the subdelegation is expressly or implicitly precluded by other legislative provisions. ${ }^{48}$ The specifics of the particular subdelegation may also be pertinent. For example, an inference of authority to delegate may become more difficult as the importance of the power at stake in-

42. Seldom is a claim of unconstitutionality against a subdelegation successful. See $1 \mathrm{~K}$. Davis $\S 9.06$, at 635 , discussing Florida Dry Cleaning \& Laundry Bd. v. Economy Cash \& Carry Cleaners, 143 Fla. 859, 197 So. 550 (1940).

43. E.g., 22 U.S.C. $\$ 2658$ (1970) (Secretary of State).

44. E.g., 29 U.S.C. $\$ 154$ (a) (1970) (NLRB); see 1 K. Davis $\$ 9.02$, at 622 n.27.

45. There have been frequent calls for greater subdelegation of tasks by top level administrators, particularly among federal agencies, in order to increase the efficiency of operations and to preserve time for significant policy decisions at the top. See generally $1 \mathrm{~K}$. Davis $\$ 9.01$; K. Davis $\$ 9.01$ (Supp. 1970) (referring to the 1941 Report of the Attorney General's Committee on Adininistrative Procedure, the Hoover Commission Report of 1949; the 1952 Wolf Management Engineering Company study of the Interstate Commerce Commission, and President Kennedy's message to Congress in 1961).

46. See Fleming v. Mohawk Wrecking \& Lumber Co., 331 U.S. 111 (1947); Note, Subdelegation by Federal Administrative Agencies, 12 STAN. L. Rev. 808, 821 (1960).

47. E.g., Cudahy Packing Co. v. Holland, 315 U.S. 357 (1942). In Cudahy, the Court found that Congress had explicitly made certain of an adıninistrator's powers delegable while leaving others unmentioned. The Court concluded that since Congress had seen fit to make explicit provision for delegation in some instances, the failure to provide such power in other instances provoked the inference that the power was lacking. Cudahy has been severely criticized on the ground that congressional grants of explicit power to delegate are in fact totally haphazard and therefore fail to justify the inference. See $1 \mathrm{~K}$. DAvIS $\$ 9.04$.

48. Fleming v. Mohawk Wrecking \& Lumber Co., 331 U.S. 111 (1947). 
creases $^{49}$ or as the responsibility of the subdelegatee decreases. ${ }^{50}$ The less discretion involved in the task, the more likely it is that the task can be subdelegated ${ }^{51}$ - a principle sometimes represented by the statement that ministerial, not discretionary, powers may be subdelegated. ${ }^{52}$ And if review of the decision by the officer or board originally assigned the power is available, the subdelegation is more likely to succeed. $^{53}$ Finally and not surprisingly, commentators have advocated what they call a "functional" approach-subdelegation should be permitted whenever it contributes to the workability of a program. ${ }^{54}$ Some courts appear to have recently adopted this perspective. ${ }^{55}$

\section{Formal GovernaNCE StRUCTURES IN PUblic Higher EduCATION ${ }^{56}$}

As the preceding section suggests, a governing board's legal authority over public higher education must derive ultimately from a state legislative or constitutional provision. Some state constitutions directly establish individual institutions of higher education or state-wide boards. ${ }^{57}$ More often, the state constitutions simply authorize the legislature to do so. ${ }^{58}$ Useful generalizations are few since the legislative or constitutional provisions are of varying vintage and the category "public higher education" includes a diverse range of institutions and

49. E.g., Cudahy Packing Co. v. Holland, 315 U.S. 357 (1942) (Court would not lightly infer imphed power to delegate subpoena power).

50. See $1 \mathrm{~K}$. Davis $\$ 9.01$, at 616 .

51. See Lewis v. NLRB, 357 U.S. 10 (1958).

52. But see $1 \mathrm{~K}$. DAvrs $\S 9.06$, at 638 (warning that the generalization is not always followed).

53. E.g., NLRB v. Duval Jewelry Co., 357 U.S. 1 (1958?

54. See 1 K. Davrs $\$ 9.07$, at 639. Professor Davis, objecting to the Supreme Court's sometimes excessively meticulous statutory construction in subdelegation cases, suggests that the Court "look beyond the literal words to the basic congressional purpose to produce a sound and workable system." Id. Davis' view would lead the courts to recognize subdelegation of power whenever necessary to effect the workability of a statutorily framed administrative structure.

55. E.g., Freeman v. Brown Bros. Harriman \& Co., 250 F. Supp. 32 (S.D.N.Y.), aff'd, 357 F.2d 741 (2d Cir.), cert. denied, 384 U.S. 933 (1966).

56. Glenny \& Dalglish, Higher Education and the Law, in PERKINS REPORT 173, provides a comprehensive summary.

57. E.g., MONT. CoNST. art. XI, § 11: "The general control and supervision of the state umiversity and the various other state educational institutions shall be vested in a state board of education. . . ."

58. E.g., Nev. Const. art. 11, § 4: "The Legislature shall provide for the establishment of a State University which shall embrace departments for Agriculture, Mechanic Arts, and Mining to be controlled by a Board of Regents whose duties shall be prescribed by law." Sometimes municipalities arc authorized to establish institutions. See, e.g., IIL. ANN. STAT. ch. 122, § 13-12 (Smith-Hurd Supp. 1974) (junior colleges). 
agencies, but the following is a broad outline of public higher education structures.

\section{A. Institutional Authority}

Traditionally, statutes or constitutions have vested general power in a board of trustees. ${ }^{59}$ The oldest provisions, while specific regarding the exercise of such powers as einployment, property, and financial manageinent, ${ }^{60}$ had relatively little to say about other matters of institutional governance. ${ }^{61}$ More recently, explicit grants of authority have been introduced on subjects such as academic affairs and student conduct. $^{02}$ But legislation seldoin contains specific criteria to guide the exercise of the delegated powers.

In most states the grant of institutional governing authority to the board of trustees ends the legislative inandate; powers or duties are not conferred directly upon subordimate officers or bodies, such as the faculty. ${ }^{63}$ A few exceptions exist: the Michigan legislature, for instance, has directed that the faculty of Michigan State University "shall pass all rules and regulations necessary to the government and discipline of the college and for the preservation of morals, decorum and health." ${ }^{\circ 4}$ But by and large, the operating authority of the school administration, faculty and student bodies, and institutional committees flows directly or indirectly from the board of trustees. ${ }^{05}$ Traditionally, the power to make such delegations lias seldoin been exphicitly proat 98.

59. E.g., CAL. Educ. Code $§ 22,600$ (West Supp. 1974); see Harris, supra note 13,

60. E.g., ch. 406, \$§ 4-18, [1907] Pub. Laws of N.C. 597-601 (repealed).

61. See Foley v. Benedict, 122 Tex. 193, 55 S.W.2d 805 (1932).

62. E.g., N.Y. EDuc. LaW $\$ \S 208-09$ (McKinney 1969).

63. E.g., VA. CODE ANN. \$ 23-9.2:3 (Repl. vol. 1973).

64. Mich. Comp. Laws ANN. $\$ 390.114$ (1964). In addition, the Michigan legislature has delegated certain powers and functions to the president, faculty, business manager, and various subordinate officers of Michigan State University. Id. $\S \S 390.113-$ .120 .

65. See note 10 supra. The American Association of University Professors' (AAUP) position is that:

The faculty has primary responsibility for such fundaniental areas as curriculum, subject matter and methods of instruction, research, faculty status, and those aspects of student life which relate to the educational process. On these matters the power of review or final decision lodged in the governing board or delegated by it to the president should be exercised adversely only in exceptional circumstances, and for reasons communicated to the faculty. It is desirable that the faculty should, following such comnuunication, have opportunity for further consideration and further transmittal of its views to the president or Board. American Association of University Professors et al., supra note 9 , at 98.

For an empirically based profile, see Report of the Survey Subcommittee of Committee T, 57 A.A.U.P. BuLL. 68 (1971). 
vided in the enabling legislation. ${ }^{68}$ Although no extensive study of board delegations has yet taken place, those familiar with the processes of higher education will suggest that these delegations are haphazard and poorly documented.

\section{B. Centralized Authority}

Soine degree of centralized authority over higher education has long existed in several narrow areas, as in the power of state boards of education to set accrediting standards for such programs as teacher training and in the power of certain administrative officials like state auditors to deterinine budgetary and accounting procedures. ${ }^{67}$ But the precipitous rise in the demand for higher education in the past two decades and the associated increase in public expenditures has generated a demand for more compreliensive centralized control over higher education decision-making in order to use limited resources more efficiently. ${ }^{68}$ Accordingly, state after state has moved away from individual institutional autonomy toward centralization of authority through the creation of administrative superstructures. ${ }^{69}$ Recent federal legislation and funding incentives have encouraged the development of such structures for all post-secondary education. ${ }^{70}$ Only two states currently liave

66. For examples of exceptions, see IND. STAT. ANN. $\$ 28-6405$ (1970) (power to delegate "such authority as it may possess" so long as the authority is revocable at will); CaL. Const. art. 9, $\$ 9$ (power "to delegate to its committees or to the faculty of the University, or to others, such authority or functions as it may deem wise"). A 1973 Office of Education study noted that "provision for maximum delegation of authority to the institutional executives and their faculties" is increasingly included in new legislation. Harris, supra note 13, at 103; see, e.g., WASH. Rev. CODE ANN. § $28 \mathrm{~B} .10 .528$ (1971):

The governing boards of institutions of higher education shall have power, when exercised by resolution, to delegate to the president or his designee ... any of the powers and duties vested in or imposed upon such governing board by law. Delegated powers and duties may be exercised in the name of the respective governing boards.

Similarly, more attention has recently been given to the power of the boards' delegatees in turn to delegate some of their power. See, e.g., The Executtve Planning CommitTEE OF THE UNIVERSITY OF OKLAHOMA, THE FUTURE OF THE UNIVERSITY 167 (1969):

As a matter of policy, all authority delegated by the Regents should be delegated through the President. Appropriate limitations on his authority or on his power to redelegate should be expressed; otherwise, he should have discretion whether or not to delegate all or any part of his authority.

Mr. McGrath has called for "explicit and definitive" delegations to the president. McGrath, supra note 8, at 191.

67. Harris, supra note 13 , at 100.

68. See NEWMAN REPORT 24, 26; Harris, supra note 13, at 97.

69. Harris, supra note 13, at 97. Another development has been the growth of interstate compacts for education. See D. Horndy, Higher Education AdMission Law SERVICE $\mathbb{\text { II }} 8$ (1974).

70. See McKinney, Establishment of State Postsecondary Education Commissions, 
no state-wide agency with a role in the affairs of higher education. ${ }^{71}$

The scope of formal authority assigned to these centralized agencies varies significantly from state to state. The range is from statewide governing boards in charge of all state institutions to coordinating boards, some of which have regulatory or only advisory powers which are generally focused on planning, budgeting, and service functions, others of which have powers limited to certain categories of postsecondary education. Some commentators predict continued movement toward state-wide governing bodies. ${ }^{2}$

The powers of a state-wide board are generally explicit. If it is a governing board, powers to establish admissions criteria, ${ }^{73}$ approve faculty ${ }^{74}$ or regulate curriculum may be specified. ${ }^{75}$ If it is a coordinating board, the powers generally involve review of budgets and proposed educational programs as well as long-range planning. ${ }^{76}$ But, as with individual institutions, seldom does the legislation provide standards for implementing that power beyond the exhortations "which in its judgment will best serve the interests of the state" or "as it deems appropriate." Explicit provisions for subdelegation of the power are likewise rare.

4 HIGHER EDUC. IN THE STS. 185, 186 (1974) (between March 1, 1974, and the April 25,1974 deadline, 43 states established such commissions, 15 by establishing new commissions, 19 by designating existing agencies, and 9 by augmenting existing agencies). The statutory requirement is a

State Commission ... which is broadly and equitably representative of the general public and public and private nonprofit and proprietary imstitutions of postsecondary education in the State including community colleges ...., junior colleges, postsecondary vocational schools, area vocational schools, technical

institutes, four-year institutions of higher education and branches thereof

as a prerequisite to certain financial assistance when and if such assistance becomes available in significant quantity. 20 U.S.C. $\$ 1142 a$ (a) (1970).

71. R. Berdari, Statewide Coordination of Higher Education 20 (1971) (Deleware and Vermont). Nimeteen states liave some form of consolidated governing board, twenty-seven states have state-wide coordinating boards, and two states have a voluntary association. Id. at 20-21. For a description of the legal bases and powers of boards of higher education in each of the fifty states, see R. WILLIAMS, LEGAL Bases OF BoARDS of Higher EDucation IN FifTy States (1971).

72. E.g., Harris, supra note 13, at 102. Examples of the trend are North Carolina and Wisconsin. See L. Glenny, R. Berdahi, D. Palola \& I. Paltridge, Coordinating HIGHER EDUCATION IN THE '70s 1-5 (1971) (pointing out historical preference for coordinating boards, but expressing concern over reversal of the trend).

73. E.g., ORE. REV. STAT. $\$ 351.070(1)$ (g) (1974).

74. E.g., ARtz. Rev. Stitat. ANN. \& 15-725A(2) (Supp. 1974).

75. E.g., Fla. Stat. ANN. \$ 240.042(g) (Supp. 1974-75).

76. E.g., N.C. GEN. STAT. \$ 116-11 (Supp. 1974).

77. E.g., ARIz. REv. StAT. ANN. \$§ 15-725, A(6), (7) (Supp. 1974). 


\section{Special-Purpose Authority}

Some autlority over state higher education policy derives from sources other than the state government. Financial assistance from the federal government commonly comes with strings attached. Institutions seeking to preserve their tax-exempt status may have to comply with rulings of the Commissioner of Internal Revenue in such matters as development of a political science curriculum or operation of a student newspaper. ${ }^{78}$ The racial and sexual complexions of their student bodies and their faculties may be determined by the Office for Civil Riglits or the Equal Employment Opportunities Commission. ${ }^{79}$ Admittedly, all of this extra-institutional and extra-state authority is voluntary in the sense that the financing or the tax exemptions can be rejected, but for most state colleges and umiversities today that choice is illusory. If the question is confronted at all, it is likely to be in terms of whether to rely on federal assistance with a consequent general loss of independence-not in terms of the specific policy decisions associated with qualifying for funding, for example, whether to admit more women.

In similar fashion, accrediting agencies establish the number of seats and books for a library, and donors determine what students receive financial assistance and what departments receive endowed chairs. Professional or umion organizations may set standards which an institution must meet to avoid the consequences of public censure or to confront the recent threat and reality of strikes. And, of course, a host of informal but powerful influences are exerted by groups such as alumni, potential and existing donors, potential and existing students, and the community in which the institution is located.

\section{Application of Legal Principles Regarding StRUCTURES TO HIGHER EDUCATION}

Given this background, it is readily apparent that application of delegation and subdelegation constraints in undifferentiated fashion to

78. E.g., Rev. Ruls. 72-512 to $-513,1972-2$ CuM. BuLL. 246-47. Whether a state institntion of higher education is for tax purposes a state agency, and exempt from income taxation because of that status, see INTERNAL REVENUE CODE of 1954, $\$ 115$, or an organization for "educational purposes" exempt under the more restrictive standards of section 501(c)(3), is presently unclear. There is no Internal Revenue Service ruling on point and extant rulings seen to leave the question open. If public universities and colleges must qualify under section 501(c)(3), then restrictive.standards such as Revenue Ruling 72-512 apply to its operations.

79. See, e.g., Department of Health, Education, and Welfare, Education Programs and Activities Receiving or Benefiting From Federal Financial Assistance, 39 Fed. Reg. 22,227 (1974); cf. EEOC Decision No. 74-53, 2 CCH LAB. L. ReP. EMPL. PRACTICES II 6410 (Nov. 12, 1973). 
higher education produces a number of potential legal problems. With regard to centralized authority, for example, the following questions may arise: (1) does legislative assignment of power to a state-wide board to govern or coordinate all higher education in the state with only vague standards for exercise of that power amount to an improper delegation; and (2) if individual boards are allowed to inake certain decisions, has there been an improper subdelegation of a state-wide board's authority? Where authority has been delegated to a board of trustees to operate an individual institution, similar issues may be raised: (1) is a particular delegation void if it does not contain sufficient standards (new educational programs undertaken by an institution might even be beyond its powers); and (2) if all power is legislatively assigned to the particular board but decision-making is shared with students or faculty, has there been an improper subdelegation of authority? Other potential legal problems are less obvious and perhaps more coinplex-for example, approval of a research program that carries implications for admissions may have been granted at an inappropriate level. While some of these issues are unlikely to be argued as a matter of federal law, they retain significant currency under state law principles ${ }^{80}$ unless the conventions of administrative law somehow do not apply to higher education. The following sections discuss the judicial treatment of such issues as they have been raised in the context of higher education. ${ }^{81}$

\section{A. Delegation in Higher Education}

(1) Tendency Toward Recognition of Broad Delegations. Although only a few cases have directly confronted the application of del-

80. See note 35 supra and accompanying text.

81. Little in the way of separate attention has been given the category of constitutionally autonomous institutions in either the judicial decisions or the analysis of this Article. Strictly speaking, the conventional delegation question is absent since power is assigned to the board directly by the constitution, not by the legislature. For the same reason, the permissibility of delegation and subdelegation are both questions of constitutional interpretation. Insofar as constitutional interpretation demands greater sensitivity than statutory construction, this factor might argue for a broader construction of a board's powers. But see Nord v. Guy, 141 N.W.2d 395 (N.D. 1966) (constitutionally established state board of higher education with power for the "control and management" of state institutions cannot be delegated legislative authority to make decisions respecting the provision of facilities such as classroom buildings). But since representative principles of one sort or another lie behind the varying trustee selection devices for constitutionally autonomous institutions (some trustees are even popularly elected), excessive delegation from the board (which would be subdelegation in the case of a legislatively established institution) can still be a matter of concern. See Searle v. Regents of Univ. of Cal., 23 Cal. App. 3d 448, 100 Cal. Rptr. 194 (1972). For a general treatment of the legal status of constitutionally autonomous institutions, see L. GLENNY \& T. DalgLish, supra notte 14, ch. 1. 
egation constraints to public higher education, those few reflect a treatment similar to that in other areas of administrative law. For example, the trend towards recognizing wider delegations can be seen in a growing judicial willingness to find that a particular power was delegated in the first place. ${ }^{82}$ The Texas courts, for example, have construed authority to promulgate rules and regulations "necessary for the successful management and government of the University" to confer power to set admissions qualifications, ${ }^{83}$ including the authority to exclude woinen. ${ }^{84}$ When the question was disciplinary exclusion, a Texas court recognized an implied or inherent power to enforce order on the campus:

We are not advised as to the nature of rules and regulations, if any, adopted under the authority of these statutes but without such knowledge it is our opinion that the [delegation] statutes imply the power and if they do not so imply then that the power is inherent in University officials to maintain proper order and decorum on the premises of the University and to exclude therefrom those who are detrimental to its wellbeing. ${ }^{85}$

82. A nineteenth century Indiana decision exemplifies the early restrictive reading of the power conferred. The Indiana Supreme Court reasoned that since the Purdue Board of Trustees had been delegated no explicit power over admissions, it must admit "every inhabitant of this State, of suitable age, and of reasonably good moral character, not afflicted with any contagious or loathsome disease, and not incapacitated by some mental or physical infirmity . . . " State ex rel. Stallard v. White, 82 Ind. 278, 284 (1882). This was so even though the Board of Trustees had been delegated authority to "do all acts necessary and expedient to put and keep said university in operation, and make all by-laws, rules and regulations required or proper to conduct and manage the same." Id. The right of admission would not be enforced, however, in the absence of sufficient space in the university. Id. at 285.

As late as 1963, a Wisconsin Attorney General's opinion ruled that state college and university regents could not limit enrollment on the basis of available appropriations when their statutory authority did not explicitly give them that power. 52 Op. Wrs. ATT'Y GEN. 217 (1963). By statute, the University Board of Regents had explicit authority to determine moral and educational qualifications; the State College Regents had explicit authority to set standards in addition to good and moral character. Id. at 218. In 1972, the Ohio Attomey General ruled that a board statutorily given "full power and authority on all matters relative to the administration" of a university could nevertheless not fund a legal aid clinic for students on the ground the clinic was not "reasonably incidental to the University's program of higher education." OP. OHro ATT'Y GEN. No. 72-023 (Apr. 3, 1972).

83. Foley v. Benedict, 122 Tex. 193, 204, 55 S.W.2d 805, 808 (1932); see 1941 Op. OHIо ATT'Y GEN. 153 (power to "control and manage the institution," id. at 155, and "to do any and all things necessary for the proper maintenance and successful and continuous operation" permits refusal to re-register students who failed to pay their rent in off-campus housing, id. at 159 ).

84. Heaton v. Bristol, 317 S.W.2d 86, 96 (Tex. Civ. App. 1958). But cf. Foltz v. Hoge, 54 Cal. 28, 33-35 (1879) (Hastings Law School cannot exclude women).

85. Morris v. Nowotny, 323 S.W.2d 301, 312 (Tex. Civ. App.), cert. denied, 361 U.S. 889 (1959). 
Thus, modern authority supports a broad reading of an institution's power. Indeed, the Illinois Supreme Court has said that the mere establishment of a state university automatically confers "absolute power to do everything necessary in the management, operation and administration of the university." ${ }^{86}$ The question at issue was the authority to hire a lawyer, ${ }^{87}$ but the Illinois court spoke nnore broadly, holding that the institution, simply on account of its existence, was entitled to "formulate and carry out any educational program it may deem proper with complete authority over its faculty, employees and students, as well as all questions of policy." 88 In a later case, that authority included the right to operate a television station. ${ }^{89}$

(2) Permissibility of Delegations. The permissibility of delegations has been debated largely in the context of state-wide boards rather than individual institutions. No historical trend is apparent-the cases, like the state-wide boards, are relatively inodern. Nevertheless, the decisions range from those that require legislative standards to those that have a less restrictive focus on the delegatee's standards and pro-

86. People ex rel. Board of Trustees v. Barrett, 382 Ill. 321, 341, 46 N.E.2d 951, 961 (1943). See also State ex rel. Curators of Univ. of Mo. v. McReynolds, 354 Mo. 1199, 1204, 193 S.W.2d 611, 613 (1946):

Although the Legislature has specifically authorized cities to issue revenue bonds, the fact it has not given the curators such express power does not prevent the implication of such power. The broad powers historically exercised by the curators without specific legislative authority or appropriations present a different situation from an ordinary municipal corporation depending entirely upon taxation for its support and with powers rigidly limited by statute or charter.

87. Missouri courts reached a similar decision over the power to issue revenue bonds. State ex rel. Curators of Univ. of Mo. v. Neill, 397 S.W.2d 666, 670 (Mo. 1966).

88. 382 Ill. at 345, 46 N.E.2d at 963 ; accord, Rheam v. Board of Regents, 161 Okla. 268, 18 P.2d 535 (1933):

"The Board of Regents have the imphed power to do everything necessary and convenient, where it is not prohibited either express or implied, by law, to accoinplish the objects for which the institution was founded."

Under that rule we are not required to look for grants of power to the Board of Regents of the University, but for limitations on its power, in order that we inay determine whether or not the act of the defendant in question in this case has been prohibited. Id. at $271,18 \mathrm{P} .2 \mathrm{~d}$ at 539 , quoting Connell v. Gray, 33 Okla. 591, 600, 127 P. 417, 420 (1912).

But cf. Association of N.J. State College Faculties v. Board of Higher Educ., 112 N.J. Super. 237, 242-50, 270 A.2d 744, 747-51 (1970) (although board of higher education has general supervisory powers and the duty to "set policy on salary and fringe benefits, and establish personnel policies," id. at 244, $270 \mathrm{A.2d}$ at 748 , it is not a "public employer" entitled to bargain under the Enployer-Einployee Relations Act).

89. Turkovich v. Board of Trustees, 11 IIl. $2 d 460,143$ N.E.2d 229 (1957).'But see Marquart v. Maucker, 215 N.W.2d 278 (Iowa 1974) (no power to fine for breach of parking regulations even though university had power to establish and operate parking lots). 
cedures. In Nord v. Guy, ${ }^{90}$ an example of the former, the North Dakota legislature had attempted to empower the constitutionally established State Board of Higher Education to issue general obligation bonds and set student fees in order to finance various physical facilities at state institutions in North Dakota. The purpose of the statute (and the only standard for allocating facilities) was "the advancement of the citizens of this state through making available more adequate facilities for higher education in the state of North Dakota, thereby promoting the economic welfare of the citizens of the state and the economic progress of the state." The North Dakota Supreme Court found that the legislature had improperly delegated legislative authority. ${ }^{22}$ The defect was that the legislature had "not determined the question of the necessity of any particular type of building, at any particular institution, nor laid down any rule to guide the Board of Higher Education in determining these questions." 33

Shelton College v. State Board of Education ${ }^{84}$ is a distinct contrast. There, the New Jersey State Board was delegated power to decide whether an institution of higher education could issue degrees. The legislatively assigned goal was simply to "[a]dvance the education of people of all ages." 95 The New Jersey Supreme Court recognized that the legislature had enunciated the end while leaving the choice of means to the State Board:

The statute does not tell the State Board what standards should be met by a college worthy of the power to confer a degree, nor does the statute specify areas within which the school's capabilities should be tested. Instead the whole subject is committed to the judgment of the State Board with a statement of the goal rather than of the path to be followed to reach it. ${ }^{96}$.

But the absence of standards did not void the delegation. ${ }^{97}$ Instead, the New Jersey court pointed out that the legislature could reasonably

90. 141 N.W.2d 395 (N.D. 1966).

91. Id. at 396.

92. The Court concluded that the legislature had improperly delegated authority to "declare the policy of the law and fix the legal principles which are to control." Id. at 404; cf. Lewis Consol. School Dist. v. Johnston, 256. Iowa 236, 249-51, 127 N.W.2d 118, 127-28 (1964) (invalidating delegation to State Superintendent of Public-Instruction to formulate standards, rules, and regulations for the operation of elementary and secondary education).. .

93. 141 N.W. $2 \mathrm{~d}$ at 404 .

94. 48 N.J. 501, 226 A.2d 612 (1967).

95. Id. at $516,226 \mathrm{~A} .2 \mathrm{~d}$ at 620 . .

96. Id.

97. Those courts willing to infer a delegation where none is explicit, see text accompanying notes 82-89 süpra, presumably fall in this camp as well, for where.the delegation is not explicit, there are unlikely to be firm legislative standards. 
have believed the Board to possess more expertise and to be more capable of fitting standards to "a changing educational scene." "delegated power must be exercised reasonably in its substantive aspects and . . . the procedural demands of due process must be honored whenever they apply,"09 the delegation was allowed to stand. Similarly, when the power at issue was that of the Mississippi Board of Trustees of State Institutions of Higher Learning to enact traffic rules for the campuses of institutions under its supervision, ${ }^{100}$ a federal court found "no real problem" in the absence of detailed standards. The mere direction to enact traffic regulations was "reasonably adequate considering the field to be occupied and the nature of the activities to be regulated."101 The court found it sufficient that adequate safeguards were available in the application of the regulations-since all violations were to be prosecuted in a Justice of the Peace court, any problems of vagueness or indefiniteness as to individual defendants could be treated on a case-by-case basis. ${ }^{102}$

98. 48 N.J. at 517, 226 A.2d at 621. Similarly, in Wampler v. Trustees of Ind. Univ., 241 Ind. 449, 172 N.E.2d 67 (1961), the legislature had given power to condemn land to a university board of trustees whenever the board "shall deem it necessary or desirable for the welfare or convenience of such institution," id. at 452,172 N.E.2d at 69. Although acknowledging the requirement of legislative standards, id. at 453,172 N.E.2d at 69 , the court sustained the delegation on the grounds that the purpose of the authority was to meet university expansion problems and that a board of trustees was "best qualified" to determine when more property was needed, id. at $453-54,172$ N.E.2d at $69-70$.

99. 48 N.J. at 518, 226 A.2d at 621; see Newman v. Graham, 82 Idaho 90, 94, 349 P.2d 716, 718 (1960) (dictum) (although legislature failed to provide criteria for admissions, governing board could determine qualifications so long as they were not arbitrary).

100. Cohen v. Mississippi St. Univ. of Agriculture and Applied Science, 256 F. Supp. 954, 954 n.1 (N.D. Miss. 1966).

101. Id. at 961. (The court found the same analysis applicable for both state and federal law.) See also Iowa Hotel Ass'n v. State Bd. of Regents, 253 Iowa 870, 87778,114 N.W.2d 539, 544-45 (1962) (sustaining delegation to charge and collect fees from students for construction and use of the buildings).

102. $256 \mathrm{~F}$. Supp, at 961 . It is possible to locate in several of the decisions a movement away from the requirement of legislative standards to a focus on the expertise of the delegatee and on what standards and procedures the delegatee itself has provided. In Foley v. Benedict, 122 Tex. 193, 55 S.W.2d 805,808 (1932), for example, the University of Texas was legislatively authorized to promulgate rules and regulations, the only standard being "necessary for the successful management and government of the University." In upholding the University's decision not to readmit a medical student who had accirmulated academic deficiencies, the court paid no attention to the ambiguity of the legislative standard. The court did, however, refer to several factors in reaching its decision. First, it quoted approvingly from other decisions suggesting that school boards had a special competence in such matters. Id. at 201-02, $55 \mathrm{~S} . \mathrm{W} .2 \mathrm{~d}$ at 809 . Second, it pointed out that each freshman class received a clear explanation of the rules the day after registration. Id. at 198, 55 S.W.2d at 807 . Third, it recounted the rules 
Thus, while courts are increasingly ready to find that a questioned power has been delegated to a university, when the legislature fails to provide specific standards there are examples of judicial hostility to delegation as well as of judicial acquiescence. Most modern commentary would decry the former. ${ }^{103}$ The impontant lesson for our purposes, however, is that neither judicial philosophy appears to have recognized anything unique about higher education that might call for special treatment. ${ }^{104}$

\section{B. Subdelegation in Higher Education}

(1) Recognition of Subdelegations. The subdelegation cases in higher education ${ }^{105}$ have also received judicial treatment similar to that in other areas of administrative law. First, whatever the traditions of autonomy or independence, it is clear that a higher education official or entity cannot legally exercise powers unless there has been a subdelegation from an agency with delegated power. As the Arkansas Supreme Court said in considering the admission and exclusion power of

in detail. Id. at 195,55 S.W.2d at 806. Although the court did not explicitly refer to this factor, the rules concerning requirements and grades were unambiguous. Fourth, the court said that the rules and regulations promulgated by the institutiou "must be reasonable and not arbitrary." Id. at 200, 55 S.W.2d at 808.

Similarly, in Newman v. Graham, 82 Idaho 90, 349 P.2d 716 (1960), a student attacked the delegation to a board of trustees of the power to set out-of-state tuition fees and argued that the regulation in question precluded the acquisition of residential status once a student had enrolled. On appeal, the student waived the delegation issue and won on the argument of arbitrariness. The Idaho Supreme Court said: "It is the denial to the applicant of an opportunity to be heard in the matter, within a reasonable time, that constitutes the objectionable feature of the regulation here considered." Id. at 95 , 349 P.2d at 719.

103. See, e.g., 1 K. Davis $\$ 2.01$.

104. Shelton College, it is true, referred to agency expertise and the rapidity of change as factors sustaining the propriety of a delegation, but those are arguments common to all delegation cases.

105. Most subdelegation cases in higher education have involved the institutional level and below. This area has previously been identified as one of concern: "Rather than improper delegation of power, the problem at the college and university administration level seems rather to be one of subdelegation of rule-making and adjudicative functions and of vagueness of rules which are intended to guide student conduct." Blackburn, Some Thoughts on the Administrative Process as a Means of Revoking the Public Education Benefits, 47 NeB. L. Rév. 528, 542 (1968) (footnote omitted). For thoughtful criticism of some of the cases, see Note, Judicial Review of the UniversityStuderit Relationship: Expulsion and Governance, 26 STAN. L. REv. 95, 121-27 (1973). Few cases have yet considered the permissibility of subdelegations from a centralized agency to an individual institution. Recent trends toward greater centralized control perhaps make this type of subdelegation a likely area for future dispute, for it is said that institutions often succeed in "captur[ing]" suich agencies. L. GLENNY \& K. DALGLISH, supra note 14 , at 63. 
a medical school, "No one to whom duties are [sub]delegated is empowered to do other than discharge the obligations expressly conferred or necessarily implied. Beyond this point the act consummated under official guise becoines personal and is subject to a court's restraining command."100 But the more difficult question is what language or actions are necessary to constitute a subdelegation. Power granted to make "such administrative arrangements" as "cannot well await" has been construed to give a university president authority irrevocably to accept a faculty member's resignation. ${ }^{107}$ On the other hand, expressly subdelegated power to reduce admissions requirements together with silence about raising them has been said to preclude presidential action on the latter. ${ }^{108}$ Authority to enforce "additional academic standards" precludes a college faculty from enforcing behavior standards when there is a separate unversity faculty discipline committee. ${ }^{109}$ Power to "authorize and supervise all courses and curricula" does not include power to designate who shall teacli a course when the regents have expressly retained power to make appoimtments to the faculty. ${ }^{110}$ The

106. Coffelt v. Nicholson, 224 Ark. 176, 180, 272 S.W.2d 309, 311-12 (1954) (dictum). In Cohen v. Mississippi St. Univ. of Agriculture and Applied Science, $256 \mathrm{~F}$. Supp. 954 (N.D. Miss. 1966), the institution had to admit that amendments to its parking regulations had never been approved by the Board of Trustees of State Institutions of Highcr Learning as the statute required and that they were therefore "without legal authority and amounting in law to a nullity." Id. at 958-59 n.12. Other problemsinadequate publication and confusion in the amendments themselves-compounded the defect.

107. Kieval v. Wilson, 285 App. Div. 1203, 1203, 140 N.Y.S.2d 756, 757 (1955) (mem.) (an alternative ground of decision in Kieval was that the matter was res judicata); see Evers v. Birdsong, 287 F. Supp. 900, 905 (S.D. Miss. 1968) (dictum) (board of trustees charged with management and control had delegated authority to the president and administration who, according to the court, "must be given wide discretion in anticipating and preventing interruptions in the classroom and student activities for whicll the school is operated").

108. 24 Or. CAL. ATT'Y GEN. 152, 154 (1954): "We must conclude that by expressly permitting a reduction in the required standards, any implied authority to increase such standards is precluded" (emphasis in original).

109. Woody v. Burns, 188 So. 2d 56, 59 (Fla. Dist. Ct. App. 1966) (semble).

110. Searle v. Regents of Univ. of Cal., 23 Cal. App. 3d 448, 451, 100 Cal. Rptr. 194, 195 (1972); see Legislative Conf. v. Board of Higher Educ., 38 App. Div. 2d 478, 480-81, 330 N.Y.S.2d 688, 691-92 (Sup. Ct.), aff'd mem., 31 N.Y.2d 926, 293 N.E.2d 92, 340 N.Y.S.2d 924 (1972) (arbitrator under collective bargaining agreement who rules on procedural defects in faculty member's nonrenewal cannot give a decision that results in tenure because that is an academic judgment). But cf. Board of Educ. v. Associated Teachers, 30 N.Y.2d 122, 132, 282 N.E.2d 109, 115, 331 N.Y.S.2d 17, 25 (19.72) '(board of education can enter collective bargaining agreement whereby grievances of tenured teachers are settled by arbitration). Arguably, Searle is not a subdelegation case since the University of California Regents are constitutionally autonomous. See note - 81 supra. In other words, since the Regents receive their power from the California Constitution, their disposal of that power is delegation rather than subdelegation. This 
cases have looked to the actual language of the board or official making the subdelegation but have made little inquiry into whether the context of higher education requires a special perspective-whether, for example, historical practice demands a recognition that subdelegation has occurred $^{111}$ regardless of the board's recorded statements (or lack thereof).

(2) Permissibility of Subdelegations. In determining the permissibility of subdelegations, ${ }^{112}$ several courts have examined the statutory power of the delegatee, but these courts have not successfully articulated a suitable test for the permissibility of subdelegations. The Colorado Supreme Court, for example, quoted a statute giving the trustees of Western State College authority to "hold property for the use of said school, be party to all suits and contracts, and do all things thereto lawfully appertaining, in like manner as municipal corporations of this state," 113 and proceeded to rule that the president of the institution could not accept faculty resignations: "An effort was made by the trustees to show that they had given instructions to the president to employ and discharge inembers of the faculty, but the lower court properly

scheme seems unlike the conventional legislative delegation, however, in that it does not as clearly involve issues of democratic control or separation of powers. The Searle court treated the issue more like subdelegation than delegation, relying on its interpretation of the enabling language (constitutional) rather than on separation of powers and democratic control.

111. See, e.g., H. Mason, supra note 9, at 26-27:

[N]o argument of principle comes to mind which would entitle a board of trustees to act as the fimal or supreme authority in all the important affairs of the university-legal provisions in the board's charter notwithstanding. All the principles, traditions, and longstanding customs of university government point to the delegation of formal board powers to administration and faculty, and to the cooperation of all the institution's components in deciding on matters of importance to the institution.

112. Many of the cases denying the permissibility of a subdelegation have arisen when someone endorsing a subdelegatee's decision has challenged the right of a higher authority to reverse that decision, claiming that the higher authority's power had been effectively subdelegated. E.g., Searle v. Regents of Univ. of Cal., 23 Cal. App. 3d 448, 100 Cal. Rptr. 194 (1972); Sittler v. Board of Control, 333 Mich. 681, 53 N.W.2d 681 (1952); Legislative Conf. v. Board of Higher Educ., 38 App. Div. 2d 478, 330 N.Y.S.2d 688 (Sup. Ct.), aff'd mem., 31 N.Y.2d 926, 293 N.E.2d 92, 340 N.Y.S.2d 924 (1972); Posin v. State Bd. of Higher Educ., 86 N.W.2d 31, 35 (N.D. 1958); Worzella v. Board of Regents, 77 S.D. 447, 93 N.W.2d 411 (1958). But courts have often upheld the higher authority, generally a governing board, in reasserting its power and used the argument that subdelegations are improper in order to sustain the board's reversal of a president's or senate's decision. Thus, despite their language, these cases may alternatively be explained, not as precludimg subdelegatiou, but as determining simply that subdelegations must always be revocable. See Searle v. Regents of Univ, of Cal., 23 Cal. App. 3d 448, 100 Cal. Rpt. 194 (1972). Nevertheless, the conclusion in the text remains that the cases demonstrate no special treatment for higher education.

113. Trustees of State Normal School v. Wightman, 93 Colo. 226, 228, 25 P.2d 193, 194 (Colo. 1933). 
ruled out all evidence of such unauthorized delegation of the trustees' statutory powers and duties."114 Though the statutory language cannot be said to have compelled the results in such cases, there is some indication that a court's estimate of the importance of the power subdelegated affects its willingness to permit the subdelegation. Thus, the Michigan Supreme Court refused to permit a subdelegation to a faculty department head of power to hire professors. It observed:

[T]he instant case involved the right by contract to bind the State in the operation of one of its educational institutions over a period of time and to expend public funds in greater or less amounts. Powers of the character vested by the [delegating] statutory provisions in a board of control of an educational imstitution maintained by the State cannot be [sub]delegated to some subordinate or representative. ${ }^{115}$

In neither of these cases was any attention paid to possible peculiarities of higher education that might demand sensitive treatment of the subdelegation question. The same, undifferentiated judicial treatment is evident in the use of the other aids to statutory construction in determining the permissibility of subdelegations in higher education. ${ }^{116}$

114. Id. at 231, 25 P.2d at 195; accord, Communications Workers v. Arizona Bd. of Regents, 17 Ariz. App. 398, 400, 498 P.2d 472, 474 (1972) ("broad mandate to the Board" to "[a]ppoint aud employ . . . such . . . employees it deems necessary," "[d]etermine the salaries of persons appointed and employed," and "[r]emove any officer or employee when in its judgment the interests of education in the state so require" precludes the board from entering a collective bargaining agreement) (emphasis omitted); Worzella v. Board of Regents, 77 S.D. 447, 450, 93 N.W.2d 411, 413 (1958) (faculty tenure policy whereby President or Tenure Committee must file a complaint before Board of Regents could dismiss a tenured faculty member was an improper subdelegation where Board was authorized to employ or dismiss instructors even though a statute also provided that the Board "may delegate provisionally ... so much of the authority . . . as in its judgment seems proper"); cf. 24 OP. CAL. ATT'Y GEN. 215, 218 (1954) (where statute provides that "[s]tudents shall be admitted to the State colleges in accordance with the rules and regulations of the State Board of Education," State Board of Education may not subdelegate to Director of Education "authority to add to, modify or make exceptions to, standards adopted by the state Board for admission to the state colleges").

115. Sittler v. Board of Control, 333 Mich. 681, 686, 53 N.W.2d 681, 683 (1952).

116. The power to make "rules and regulations" is sometimes said to permit subdelegation, In re Carter, 262 N.C. $360,370-71,137$ S.E.2d 150, 157-58 (1964) (semble) (power subdelegated to student honor council), and is sometimes ignored, 24 OP. Cal. ATT'Y GEN. 215 (1954) (state board may not subdelegate to Director of Education power to add to, modify, or make exceptions to its admissions standards although it may authorize him to act "within" the standards). A history of subdelegations under an ambiguous statute may have relevance if of significant scope and duration, 24 OP. CAI. ATT'y GEN. 152, 154 (1954) (attorney general found insufficient evidence to justify "contemporaneous" or "administrative construction"), or may have no relevance at all. In Sittler v. Board of Control, 333 Mich. 681, 687, 53 N.W.2d 681, 684 (1952), the court stated, "[mt appears in plaintiff's opposition to the motion to dismiss that on other occasions heads of departments have hired assistant teachers; but such usage or custom, if it ever prevailed, cannot be availed of to enlarge the statutory powers of the board 


\section{Appropriateness of the Administrative LAW MOdeI.}

Analyzing governing authority in higher education in terms of delegation and subdelegation represents an application of administrative law principles to these institutions. ${ }^{117}$ The attempt is not surprising, for these institutions are, after all, instrumentalities of the state, ${ }^{118}$ funded by it, and organized to distribute public benefits. ${ }^{110}$ Legisla-

of control . ..." The traditional statements permitting subdelegation of "mere ministerial and administrative functions which are to be exercised in obedience to and in conformity with definite rules, guides and standards" can be found. 24 OP. CAL. ATT'Y GEN. 215, 218 (1954). A method of appeal to or review by the delegatee counts heavily, Montague v. Board of Educ., 402 S.W.2d 94, $97-98$ (Ky. 1966) (subdelegation by local board of education to University of Kentucky to supply the faculty and prescribe the curriculum of a junior college program); see Searle v. Regents of Univ. of Cal., 23 Cal. App. 3d 448, 451-52; 100 Cal. Rptr. 194, 195-96 (1972) (irrevocable subdelegations improper), particularly where procedural safeguards are provided. E.g., In re Carter, 262 N.C. $360,371,137$ S.E.2d 150, 158 (1964); cf. Woody v. Burns, 188 So. 2d 56, 59 (Fla. Dist. Ct. App. 1966) :

We are not aware of the delegation by the legislature or the State Board of Education or the Board of Regents to the faculty meinbers of any college of the higher education system of this state to arbitrarily or capriciously decide who they desire to teach, and should such delegation be attempted it would amount to creating a hierarchy contrary to all of the fundamental concepts of a democratic society.

Recently some courts have been impressed by the so-called functional argunnent. E.g., Montague v. Board of Educ., 402 S.W.2d 94, 97-98 (Ky. 1966) ("but for the joint efforts of the Board and the University the continuation of Ashland's junior college program would have been a doubtful thing.")

117. The fit is not exact. In structural terms, administrative agencies (on the federal level, where most analysis has been directed) have fallen into two general categories: the regulatory agency structured on the commission or collegial model, and the executive agency structured on the single-administrator model. The counmission model is that chosen by Congress for the major independent regulatory agencies, such as the FCC, the FTC and the ICC. These agencies have a multi-member commission authorized to carry out the tasks delegated by statute. One member of the commission is the Chairman, who may have additional powers of his own. Subdelegations of authority flow from this commission to the various conponent bureaus of the agency. The single-administrator model is found in the executive departments and other agencies. These agencies have an Administrator or a Secretary who is empowered by statute to perform the agency's functions, and who subdelegates power down through a pyramid of assistants. Generally, these executive agency administrators report directly to the President on various inatters of policy. Although higher education's centralized agencies sometimes resemble conventional independent regulatory agencies like the FTC, individual institutions are not obviously either of that category or of the category of the typical executive agency such as the Government Printing Office.

118. For a provocative recount of similarities and a skeptical treatinent of differences between universities and government bureaucracies, see Bailey, $A$ Comparison of the University with a Government Bureau, in PERXINS RaPORT 121-36.

119. See Glenny \& Dalglish, supra note 56, at 197:

[M]odern universities are also "formal" organizations, chartered by the state for the "efficient" achievement of special purposes upon the regular allocation of public funds. This fact has tended to produce a hierarchic administrative structure, and demands for central responsiveness to the public view of those fuuctions. 
tures delegate power to individual and state-wide boards with purported expertise to regulate higher education for the same reasons that legislatures have assigned administrative power in other contexts. The activity to be regulated (public higher education) has a complexity and rate of change such that legislatures generally cannot, and often prefer not, to manage the activity on a continuing basis. ${ }^{120}$ As in some other areas of administrative law, important interests are at stake-instead of the stock market or food and drug impurities, the socialization and education of future leaders or voters, ${ }^{121}$ preparation and certification for employment, and the direction of research that ultimately may affect the quality of life.

Indeed, much of the current debate over governance is analogous to that concerning other administrative agencies. The drive to secure representation of new interests on governing boards-whether faculty, students, or community representatives-parallels the demand for greater "consumer" representation on many federal and state agencies. The accusation in the late sixties and early seventies that boards of trustees capitulated to student and faculty demands and failed to exercise their full responsibilities recalls the conventional criticisin that state and federal agencies are "captured" by the interests they are assigned to regulate. ${ }^{122}$ And of course the demand for procedural due process occurs wherever government has the power of granting or withholding a benefit, whether it be education, housing, or the license to practice a profession or operate a busmess.

But administrative law specialists are increasingly reluctant to assume that one model is adequate for all the governmental agencies that operate in our society. ${ }^{123}$ Before the structural principles of orthodox administrative law are automatically applied to public higher education, therefore, closer examination of higher education is warranted to determine whether any characteristics justify different treatment. ${ }^{124}$ Stu-

120. It is true that, as with other administrative agencies, a legislature or governor can influence or control a program through means other than legislation-for example, appropriations, appointment of trustees, and the threat of legislation.

121. Morison, Some Aspects of Policy-Making in the American University, DAEDALus (Summer 1970) at 617: "To many members of the faculty the real heart of the enterprise is the undergraduate liberal arts college. Here the announced purpose is to produce broadly educated men fit for citizenship in a free society."

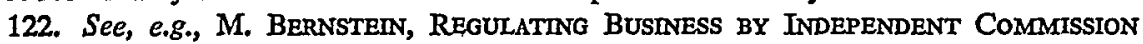
$294-95$ (1955).

123. See, e.g., Jaffe, The Illusion of the Ideal Administration, 86 HARV. L. REv. 1183 (1973). Actually, the concern has older roots. See, e.g., J. LANDIS, THE ADMINISTRATIVE Process 17-22 (1938).

124. In a book released after this Article was written, Leon D. Epstein has provided an excellent and far more exhaustive account and analysis of public higher education 
dents of higher education commonly raise three major factors in support of unique structural treatment: (1) higher education's independent historical traditions; (2) the peculiar structural needs of academic freedom in the pursuit of knowledge; and (3) the political community-like qualities of many contemporary educational establishments. The significance of these three factors as they relate to the administrative law principles of delegation and subdelegation will be examined here together with three other potentially distinguishing characteristics-(1) the reseniblance of some components of public higher education to state-owned enterprise as opposed to regulatory agencies; (2) the sometimes substantial use of private, foundation, and federal government financial support; and (3) the appoimtment and manner of compensation of governing boards. In the examination of these characteristics, the public higher education agencies will be viewed in ternis of a number of their functions: distribution of public largess, ${ }^{125}$ regulation of private activity, ${ }^{126}$ and production of a consumer and imvestment "good"-education-in competition with sectors of the private economy.

\section{A. Unique Historical Traditions}

Higher education has ancient historical roots independent of mechanisms created for government-ordered reforn. In many respects, public higher education has been a governmental adoption of an already existing social organization with its own structural traditions. This is in distmot contrast to the regulatory agencies which were created as new institutions to reform perceived social problems ${ }^{127}$ and which were often granted vague and broad powers to achieve maximum flexibility. ${ }^{128}$ These regulatory agencies liave furnished the basis for most discussion in administrative law and process.

as a state agency. While his perspective is that of political science, the considerations raised here are not greatly different from many of Epstem's-though purposes and conclusions vary. See L. Epstern, supra note 18 (especially chapters 3-5, 8-9).

125. The tuition at state institutions is frequently substantially less than the actual cost of an individual's education. The resulting deficit is largely a subsidy by the state.

126. For an individual university this function encompasses rules and regulations for students and faculty. For a governing body the rules are directed at other (often public) institutions.

127. See L. JAFFe, supra note 25, at 4: "We have said that the administrative process has been the characteristic instrument for redesigning the operation of our economic system and for effecting the required transfers of power."

128. Commentators have argued that when a legislature, without the advantage of prescience, creates these new agencies, it should be purposefully vague and allow broad powers and Inaxinum flexibility in order tliat the agency may effectively attack the problem in its various unforeseen manifestations. See, e.g., Jaffe, Book Review, 24 
What are the implications of the unique historical traditions of higher education for legal treatment of its structures? Since the establishment of state universities often represents governmental approval and adoption of a specific and extant form of social organization, the call for legislative vagueness seems misguided. In that context, a delegation of maximum powers and flexibility may be an invitation to perversion of the settled legislative objectives.

Obviously such generalizations are appropriate to only part of the current legislative activity in higher education. They do not well fit the new state-wide boards or the relatively recent special-purpose institutions like community colleges. The coordinating commissions, for example, are a new creation directed to accomplish reform ${ }^{\mathbf{1 2 0}}$ - the achievement of the most economical and efficient program of higher education for all the citizens of a state-in an area where there are no obvious solutions and educators are sliarply divided. It can hardly be said either that legislative goals are settled or that an established social orgamization is being adopted. Similarly, community colleges are often created to fill an educational void left by traditional higler education. ${ }^{130}$ The traditional calls for flexibility and broad powers with respect to administrative agencies may therefore be applicable, as will be discussed later, so that these reformist and experimental institutions can adjust to the problems as they become better defined. Courts should be sensitive to these needs.

The case of state colleges and universities operating under old legislation is more complex. Sparse language is not necessarily a vague delegation with obscure standards. A terse legislative command to establish a university, though silent about structure, may nevertheless have contained an implicit, well-defined meaning because of the historical context. Analogously, on questions of subdelegation, effioiency arguments for extensive subdelegation (or responsibility arguments

SrAN. L. REv. 587, 589 (1972): "In the early days of rate regulation, broad delegation implied a mandate for change and in the hands of sympathetic administrators resulted in change." Similarly, courts have been advised to sustain such broad delegations of power and to give an agency the benefit of the doubt when its power is challenged. Maximum subdelegation has also been touted for its efficiency.

129. It is said that "research indicates a need for adaptive state structures for postsecondary education, which encourage rather than discourage basic modifications of existing educational patterns . . . " L. GlenNy, R. Berdahl, D. Palola \& I. Paltridge, supra note 72 , at 4 .

130. Community colleges provide geographically accessible continuing education programs on a noncompetitive basis for those who have failed to complete their elementary and secondary education or desire further education short of or different from the traditional liberal arts or science degree. 
against it) should perhaps be modified by well-established university practices regarding the location of decision-making power at the time the legislature acted.

Practical difficulties, however, limit the usefulness of these observations for courts or administrators. In most cases it will simply not be possible to assert with confidence that the legislative mandate to establish a particular university carried with it a clear message regarding governance structures. While the legislative history and context (if discoverable) of a particular statute could theoretically afford such an insight, the likelihood is small; American higher education has not often enjoyed unity of purpose. Higher education historians point out a number of salient threads: ${ }^{131}$ the original church colleges narrowly designed to train the clergy and elite; the curricular and agricultural reform purposes of the Civil War era land-grant colleges; the importation of German notions of academic freedom and graduate education and of British notions of residential education; the large scale research functions of post-World War II institutions, to name a few. Some of these movements had structural implications at odds with then current ideas. The land-grant colleges, for example, were established to achieve significant reform im educational and research practices. Importation of the German notion of Lehrfreiheit implied broader faculty power at the expense of trustees. Thus, to draw firm conclusions on what power was delegated to a board or what powers could be subdelegated beyond a board, or to discover implicit standards for implementing the mission, all from a terse command to establish a umiversity, would require detailed consideration of the specific context in which a particular state institution was established and of the relative strengths of the various structural traditions in that state at the time. ${ }^{132}$ What is more, if there were ever such a time of centainty on the mission and structure of higher education, it is certainly past. Legislative establishment of an institution without specific directives today would occasion widespread

131. See generally C. JENCKS \& D. RIESMAN, supra note 10, at 1-27; C. KERR, THE UsES OF THE UNIVERSTTY 9-26 (1963); Duryea, Evolution of University Organization, in PERKINS RePort 15-37; Schenkel, Who Has Been in Power?, in POWER AND AUTHORITY 1 (H. Hodgkinson \& L. Meeth eds. 1971).

132. Three state universities were established in the eighteenth century, fourteen from 1802-53, and state institutions began to flourish after the Civil War. 1 R. HorstadTER \& C. Hardy, The Development and Scope of Higher Education in the Unted STATES 43-44 (1952). Insofar as a significant number of state institutions find their genesis in the Morrill land grant context, see $2 \mathrm{id}$. at 568, the historical argument for distinctive treatment is particularly weak. The federal legislation and the institutions established in response thereto had definite reforming purposes and were agencies designed to fill a need unserved by private higher education. Thus, they begin to resemble the conventional genesis of administrative agencies. 
disagreement over mission and structure. ${ }^{133}$ Old statutes whose pertinent provisions have remained unchanged while the institutions have undergone metamorphoses create no less disagreement. In view of the foregoing, perhaps the best that can be said is that a conventional administrative law argument seems applicable: long-standing practices by an agency deserve credence in the assessment of what is permitted under a statute whose mandate is unclear.

The argument that higher education has unique historical traditions demanding special treatment for structural disputes thus requires careful handling. From a judicial perspective, it could call for constraint of an institution that is exceeding structural restraints implicit in the apparently vague statutory language. Or, in the case of newly designed and untested programs, the argunient nay require the same presumptions and flexibility accorded other governmental agencies of reform. More often, it will simply not provide nuch assistance in determining the appropriate structure of an individual institution. But the complex historical traditions and the current controversy over alternative nuissions and structures of higher education do call for legislative indication today of the general direction a state institution is to pursue in its expenditure of state funds.

\section{B. Academic Freedom}

It is commonly asserted that the higher education enterprise requires special treatment because "academic freedom" demands a peculiar blend of authorities for governing an institution: first, there inust be substantial independence froin governmental, political, or legal intervention so that the institution may creatively order its own affairs; ${ }^{134}$

133. See Bell, By Whose Right?, in Power AND Authorrty 153, 164 (H. Hodgkinson \& L. Meeth eds. 1971):

It is startling to realize that we have not had any adequate definition of a university. The university is likened to an extended family, a secular church, a corporation, a conımunity, or it is sinıply described as a microcosm of the society. And the multiplication of its functions leads to increasing ambiguity and amorphousness about the nature of the beast- one of the central reasons for the failure to define adequate governance. If it is like a family, then one kind of standard applies; if like a political commuuity, another set of standards; if like a corporation, a third; and so ou. It is clear that elements of all these are present....

134. Cf. Glazer, Campus Rights and Responsibilities: A Role for Lawyers?, 39 THE AM. SCHOLAR 445, 447 (1970) (arguing that the lawyer's concern for protecting the individual against the state may be ill-suited to the university context):

[O]n the whole I take the position that the introduction into the university of legal principles and practices drawn from the operations of the body politic and civil society would hurt rather than lielp the universities and colleges.

$\therefore$ [U]niversities and colleges have distinct objectives, objectives that would be hampered by deploying, in the university and college setting, the full range of procedures and rights that we have developed to protect people against 
and second, there is a need for "horizontal" governance whereby appropriate members of the community of scholars cooperate and collaborate in ordering the affairs of the institution. ${ }^{135}$ These are demands seldom heard with respect to other governmental agencies. In universities, what Professor Jaffe calls the "bureaucratic virtues and vices" are especially feared. ${ }^{136}$ Orthodox administrative law is perceived as imposing a uniform hierarchical and rationalistic model derived from other state agencies but insensitive to the needs of higher education:

The rationalistic bias with which laws operate facilitates what the laws expect: clear, unambiguous delegations and subdelegations of authority, power, and accountability. The pressure, then, is to conform the behavior of individuals in the university to legally prescribed objectives, at a pace determined or fueled by a prescribed amount of funds, always with the expectation of holding people accountable. The result may be a model system of rules and laws which, when all is said and done, may not accomplish specific educational objectives but appears reasonable from an administrative perspective. ${ }^{137}$

In the delegation context, the demand for independence for public higher education at first glance seeins to call for broad legislative grants of power with minimal standards and directives, and subsequent judicial abstention. A recent text in political economy advances an explanation:

the state and its agencies. ...

... [T] ties and colleges is the advancement of knowledge through research and teaching. This is no justification for arbitrary and irrational authority, but the advanceinent of knowledge seems to demand its own settings and its own rules, and these are not the same as those that the democratic process requires. When a lawyer whose principal concern is the defense of individual rights against local police departments, vigilante groups, local and state governments, the F.B.I. and a misguided Congress, comes into such a situation, both his model and his reflexes are wrong.

Similarly, Mr. Bailey contrasts the business corporation directed toward the single purpose of making money in which a well-defined, authoritarian constitutional structure 1nay be both necessary and expedient. See Bailey, supra note 118.

135. "The collegial model of academic organization, which faculties favor, is a theory of government which ostensibly rests on the basic democratic principle that all who are affected by the government should have a voice in determining its policies and choosing its officers." E. MCGRATH, supra note 9, at 48.

136. Jaffe, supra note 123, at 1188: "[H]ighly rationalized administrations embody the advantages of stability, equality of treatinent, order, comprehensibility and predictability, and the defects of rigidity and displacement of objectives by bureaucratic routine."

137. Glenny \& Dalglish, supra note 56, at 197; see YALE UNIVERSITY, RePorT of THE PREsideNT, 1967-68, at 26 (1968) (Kingman Brewster): "Ultimately it is the sharing of purposes, however, not the allocation of rights and duties and powers, which keeps a university intact. Yale is a community of good will and loyalty more than it is a regime of laws." 
[W] here goals and values are ambiguous or multiple, a public organization's elite may press for one definition or another and, within the boundary of political feasibility, may allocate some resources internally in pursuit of their choice. Examples might include a state college .....138

Historically, many state legislatures have imphicitly recognized this concern. $^{139}$ The Carnegie Commission, for example, has concluded that while there are differences of degree among states and institutions, public colleges and universities have generally received more autonomy than other state agencies. ${ }^{140}$ Twenty-three states give some form of constitutional recognition to higher education whereas few agencies of elementary and secondary education are so recognized. ${ }^{141}$ Forty states grant corporate powers to higher education boards and many are given direct borrowing power; ${ }^{142}$ less often is such authority conferred on other state agencies. By statute many higher education boards are explicitly accorded wide discretion or complete autonomy on such policy matters as admissions criteria, degree requirenıents, and academic programs. ${ }^{143}$

But such broad powers do not necessarily result in effective independence. Professor Jaffe lias recently theorized that the less defined and specific a final legislative expression, the more an agency is open to informal political pressures. ${ }^{144}$ Even if a vague mandate enhances the ability to generate creative developments, it will not guarantee the

138. G. Wamslex \& M. Zald, The Political Economy of Public Organizations 40 (1973). The authors go on to cite the University of California as an example:

[It] possesses most of the characteristics that thwart surveillance. Goals could scarcely be more ambiguous, and the complexity of multiple sources of funding and immense capital-outlay projects of long and varied duration make surveillance a massive task, challenging the capabilities of budget agencies or chief executive. Where the tasks of a public organization are difficult to scrutinize, control passes inward to its executive cadre, and sensitivity diminishes. Id. at 41.

139. The very existence of lay boards to govern institutions is often cited as providing independence. See, e.g., American Ass'n of Colleges \& Universities Special Task Force on Institutional Rights and Responsibilities, State Colleges and Universities and State Wide Governing and Coordinating Agencies 2 (J. Nickerson rev. ed. 1971) (unpublished mimeograph on file at the office of the Duke Law Journal, Durham, North Carolina). See generally H. Eulau \& H. QUINLey, State OfFicials and Higher EduCATION 52-56 (1970).

140. See generally Carnegie Commission on Higher Education, Capitol and Campus (1971).

141. See id. at 100.

142. $I d$.

143. Id.

144. Jaffe, supra note 123, at 1190-91. The obvious areas for "influence" in higher education are the directions of and emphasis on research, admissions and enrollment policies, and curriculum and program structures. 
political power necessary to implement them. Without specific legislative inandates to point to in justification of a program, institutions may find it difficult to withstand executive or legislative budget committee suggestions. Recent experience with public higher education does not clearly contradict the Jaffe insight. ${ }^{145}$ Those familiar with state universities will recognize that ambiguous, unultiple goals may provide unaneuvering room to the institutional elite, but that the maneuvering occurs within the context of, and often in response to, political pressures. ${ }^{146}$ What is more important, the proper scope of public higher education is currently imcreasingly controversial. Public institutions without clearly defined legislative mandates must now pursue an unidentified course among a lost of inforinal but powerful political pressures.

It nay be, of course, that despite the academic freedom arguments, independence from political pressures is not desirable for all of public higher education. The new agencies whose duty it is to organize and to implement higher education planning for an entire state without the benefit of a consensus on missions and programs inay warrant the restriotions of political oversight. Special purpose institutions not designed to provide a liberal education, but to meet manpower training needs in a state, perhaps should also be open to such pressures in designing their programs. For such institutions, broad delegations with close political momitoring may be useful.

In the context of subdelegation, the call for horizontal governance structures implies that courts should free institutions from traditional notions that certain powers can be exercised by some but not others within the institution, and that an official with power must demonstrably transfer it to the person inaking the decision. ${ }^{147}$ The subdelegation

145. Earlier experience may also be consistent with Professor Jaffe's theory. As suggested in text accompanying notes 127-33 supra, it is not at all clear that terse legislation was necessarily vague. Even if directives were vague in some respects, more of the earlier higher education programs were probably within a core definition of what was acceptable.

146. An example may be drawn from the recent experience of the North Carolina Board of Governors. When the North Carolina legislature restructured the state university system a few years ago, the Board of Governors was granted extensive authority over the state's colleges and universities, including budgetary and curriculum matters. The planning authority of the Board was, however, soon channelled by the legislature's appropriation of $\$ 15$ million as a reserve for building a politically sensitive medical school at East Carolina University. Now the Board, contrary to its previous "professionally-based recommendations," has endorsed the expansion. See Let University Carry Out lts Mission, 63 UNC-CH AlumNi Rev. 4 (Jan. 1975).

147. Perkins, Conflicting Responsibilities of Governing Boards, in PERKINS REPORT 203, 205:

The board, in its role as agent, reflects the notion that legitimacy must be con-

ferred; the faculty reflects the earlier idea that legitimacy is inherent. Here 
problem could be obviated by legislative statements that others than the trustees have specific powers-that the faculty, for example, can determine curriculum or that the students can determine the use of student fees. Such a solution, however, would not meet the additional demand for flexibility and informality, i.e., that decisions should be permitted to be made in different locations at different times in response to the pressures of the moment. While a broad legislative permission of subdelegation would partially meet this demand, conventional judicial notions of subdelegation nonetheless require some showing of specific transfers of power. The informality often demanded in higher education would be inconsistent with such "bureaucratic" demands. This argument suggests recognition and acceptance of university decisions whether or not the structural rules have been followed. ${ }^{148}$

This argument has appeal so long as it is not pressed too far. Some indication of where power lies-apart from recognition of its ad hoc exercise-is necessary to enable participants in public higher education to conduct their affairs in reliance upon established norms or to focus their energies on orderly cliange. ${ }^{149}$ Moreover, even where consensus exists within an institution, external constituents, such as taxpayers, might also be aggrieved by the mislocation of decision-making power-students, for example, being allowed to decide who shall be denied public higher education. Arguments in favor of horizontal decision-making (e.g., the desirability of students having decisive voices on disciplinary committees) may suggest greater judicial flexibility in recognizing that a subdelegation lias occurred without precise formalities, ${ }^{150}$ but these arguments do not demonstrate the irrelevance of the fundamental admimistrative law principles.

is the root of much current ambivalence about who can speak for the university: the faculty, as a community of scholars, or the administration and board, who receive their powers from the state? Each claims to be the legitimate voice, but each appeals to different concepts of legitimacy.

148. Cf. J. Corson, supra note 18 , at 45 :

[T]here is little evidence that a carefully thought-out design underkes the delegation pattern that obtains. Rather, prevailing organizational arrangements suggest that the existimg patterns of delegated authority have been established to meet specific situations in particular institutions or to reflect the strengths and weaknesses of individuals in various echelons.

Accord, KeRR REPORT 9-10: "There is more emphasis upon participation as the sine qua non to legitimize decisions and less on assigned responsibility and accountability; and more stress upon the informal and ephemeral group than upon the formal and permanent agency."

149. See note 11 supra. Those familiar with the operation of faculty government will also recognize the frequent concern of academics for abstract principles rather than simple pragmatics, resulting in intense debate over procedures and structures within a university.

150. Moreover, subdelegation of power to line officers within the administration 


\section{Campus as "Community"}

Perhaps the most frequently raised distinotive attribute of higher education is that of "community." The tradition has strong and varied historical roots. Early students in Italy grouped together for education and hired their teachers; student guilds controlled that form of higher education. Teachers then organized collegia for their own economic protection ${ }^{151}$ and the "community of scholars" concept was born. While such organizational forms have not lasted, many students pursuing a higher education im the United States today leave their homes to reside on or near campus and engage almost exclusively in campus-oriented activities during their college years. The full-service institutions that result produce community structures unknown in most other public agency activities. ${ }^{152}$ The "community of scholars" has thus taken on new meaning. Many such institutions have their own police forces, health services, commodity distributors, and communications media. ${ }^{153}$ They generate social relationships so strong that many who pass through these particular public agencies retain lifelong affiliations with them. ${ }^{154}$

Such factors, coupled with the resurgence of student power in the 1960's and students' demand for treatunent as "citizens," help to explain the frequent assertion that a university is a community and like political communities should recognize democratic forms of organization. ${ }^{155}$ Authority is not merely delegated down from the state; power must also

should perhaps be held to the stricter standards. Cf. American Ass'n of Colleges and Universities Special Task Force, supra note 139, at 9: "Accountability requires the exercise of judgment by all elements and clear delegation of responsibility and requisite authority. No officer can be held accountable in the absence of such delineation."

151. See E. McGratH, supra note 9, at 10-13.

152. Other full-service state institutions inight include state hospitals, prisons, retirement homes, and military institutions, all of which have received little administrative law analysis.

153. In Clark Kerr's words, such an institution resembles a "city of infinite variety, ... more like the totality of civilization as it has evolved and more an integral part of it." C. KERR, supra note 131 , at 41.

154. As one commentator notes: "This combination of services, along with the staff to provide them, inoves the university a long way fron being merely a community of scholars and confronts it organizationally with concerns similar to those found in local communities of comparable population size." Sauders, The University as a Community, in PERKINS REPORT 57, 75. Current reform inovements envisage significant changes in such arrangements-commuter colleges are an example of their attenuationbut at present they remain an important aspect of public higher education. Sonie have argued that campuses have become too large to be single "communities" and must decentralize into smaller communities. See H. MASON, supra note 9, at 15 , for a summary of the arguments. The explicit or implicit call for greater subdelegation has in turn been attacked as creating an unmanageable institution. Id. at 16.

155. The "community" model is an obvious contrast with the in loco parentis model previously used to justify almost absolute power of administration over students. 
be recognized as flowing up from the constituents. ${ }^{156}$ Most often this argument is used to support student demands for self-government in terms of social regulations, but it has been extended to academic affairs as well and sometimes is advanced on behalf of other "constituents" of the community, such as faculty and staff. ${ }^{157}$ If accepted as a legal concept, it would lead to the conclusion that exercised power need not always be traced to the board or legislature; that students for example have an inherent democratic authority to regulate their own conduct and discipline, perhaps even to exclude nonconforming members. The concept could be rationalized on the basis of legislative assignment of such powers, somewhat on the model of charters accorded to municipalities. In the absence of legislative inclination to do so, the pressure will be on university administrations or courts to legitimize the process.

But the question remains, should legislatures delegate, or boards subdelegate, wide powers of self-governance to faculty or students? Traditional arguments for democracy in society at large do not necessarily call for democracy within higher education. The principle that those whose interests are affected should participate in the decision, for example, does not always justify allocation of decision-inaking authority to students and faculty. Many university decisions affect interests outside the university-an expansion program is an obvious example, admissions policies another. As Professor Thompson suggests, "If the principle of affected interests by itself points toward any conclusion about university governance, it suggests control of the university by the state, which, by virtue of the wider scope of its authority, ought to be able to take into account more of the 'affected interests." "158 Similarly, the argument that popular participation will increase the likelihood of wise decisions over time, whatever its persuasiveness in the context of society at large, nust be modified when applied to higher education with its "more limited and specific purposes."159 Here, "expertise or competence . . . can be a more appropriate basis on which

156. See C. OTrEN, supra note 10, at 196: "In a system of private government, authority would also rest on legal delegation and specialized skills, but control, significantly, would be further conditioned by institutionalized acknowledgement of the consent and rights of the governed." Another component of the argument for democratic structures in a university is the claim that the university can thus effectively teach citizenship. See Perkins, supra note 19, at 12.

157. Cf. American Association of University Professors et al., supra note 9, at 96100.

158. Thompson, Democracy and the Governing of the University, 404 THE ANNALs 157, 158 (Nóv. 1972). Thompson also argues that the principle of consent of the governed is not necessarily pertinent to higher education. Id.

159. Id, at 159. 
to grant authority."160 Thus, curriculum decisions in a medical school should perhaps not be left to students, and investment and financial planning in universities generally not left to faculties. It should be clear, moreover, that the notion of community has neither historical nor current application to centralized higher education agencies, although it may affect their relationships with the individual institutions. Similarly, the argument applies with significantly less force to the mcreasing number of off-campus or commuting institutions, whose students retain or adopt membership in the larger political community and are not completely transposed to a university environment.

In short, arguments concerning higher education's community-like characteristics require careful discrimination among different programs and functions. Some activities-establishment of norms of social conduot in a dormitory, for example-may appropriately be delegated to those most affected, in this case students. Others, such as admissions policy decisions involving the determination of how subsidies for public higher education shall be distributed, should be made at a higher level-by a board or legislature perhaps, if the issue is what categories of a state's population are to be the beneficiaries of the public subsidy; by a faculty or administration if the question is who can succeed in current academic programs. Such factors clearly are primarily for legislative and administrative consideration, but a count can also take them into account in reviewing a delegation or subdelegation.

\section{Higher Education as State-Owned Enterprise}

In many respects individual institutions resemble governmentowned enterprises such as the Tennessee Valley Authority nuore than they do agencies designed to regulate private interests. Public institutions are in the business of education and, as is now obvious, are competing with private education. Although the phenomenon has not received close examination, it seems that administrative law treats agencies that regulate private economio activity differently from those that operate an enterprise ${ }^{101}$ or those that distribute goods and services. ${ }^{162}$ Of course, some higher education operations such as those of

160. Id.

161. See J. LANDIS, supra note 123 , at 21-22.

162. When government hands out licenses or welfare benefits, for example, the concern has been more with constitutional due process and the criteria employed than with other administrative concerns. Historical reasons seem to explam this latter phenomenon. For many years those challenging these agencies had to contend with the right/ privilege distinction, the argument being that as recipients of a mere "privilege" they could contest nothing. See Van Alstyne, The Demise of the Right-Privilege Distinction 
state accrediting agencies and of the more modern coordinating commissions are analogous to regulatory agencies. But even these organs of higher education liave the unique feature of regulating other public agencies rather than private enterprise. ${ }^{163}$

This aspect of public higher education is difficult to assess. It is true that administrative law commentators have sometimes suggested that government ownership avoids the complex of delegation problems, ${ }^{104}$ but these observers have not adequately articulated a rationale for that view. Perhaps the assumption is that the demands of consumers and the constraints of competition delineate the mission of the public enterprise sufficiently that detailed legislative standards and judicial control are unnecessary. ${ }^{165}$ Furthermore, maximum flexibility and independence in structural matters is necessary in order to compete effectively with private concerns and to manage the enterprise successfully; and insofar as the state agency is not directly regulating private activity, but selling a product on the open market, less significant interests are at stake to demand close scrutiny. But to the extent that public higher education is tax-subsidized, the power of consumers (students and their parents) is diminished, and the resulting lower price of public higher education removes much of the competitive constraint that private education might liave provided.168 Moreover, because higher education often entails a protracted period of consumption frequently in a residential setting, it is difficult to argue that institutions are simply selling a service and not, as any other agency, regulating the private affairs of their consumers as well. ${ }^{167}$ Unlike other enterprises, university balance slieets are not a particularly good indicator of performance for the shareholders or taxpayers. ${ }^{168}$ The diversity of

in Constitutional Law, 81 HARv. L. REv. 1439 (1968). By the time that argument was overcome, delegation/subdelegation notions were largely obsolescent, at least as a matter of federal law, and procedural due process had come to the fore.

163. The uniqueness may be decreasing as more federal agencies-HEW, for example -undertake this same function.

164. E.g., Jaffe, An Essay on Delegation of Legislative Power: 1, 47 Colum. L. Rev. 359,376 (1947).

165. Cf. R. Daht \& C. Lindblom, Politics, Economics and Welfare 427-34 (1953) (suggesting that public enterprise is more responsive to a price system while an agency is more responsive to political constraints).

166. See generally Bailey, supra note 118 (for government agencies, purpose set forth in legislation, together with public and legislative review, provides guidance; for industry, the products, sales, and profits set the purpose; less guidance is available for a multischool university).

167. To some extent, the same is true of certain categories of employees. See generally Corson, Perspectives on the University Compared with Other Institutions, in PERKINS REPORT 155-69.

168. See generally Bailey, supra note 118. 
educational goals and programs provides a sharp contrast to the narrow profit orientation of the ordinary business corporation.

In summary, state-owned enterprise and public higher education are by no means congruent. The dissimilarities are troublesome. The enterprise/regulation distinction nay soinewhat reduce the need for specificity once a legislature has defined the kind of institution it is establishing and may countenance greater subdelegation to increase efficiency, but the arguments are hardly overwhelming.

As to the centralized coordinating agencies that are not selling a service but indeed regulating an "industry," the fact that the regulated industry is itself public may suggest soine lessened concern that all the technicalities be observed. Since individual interests are ultimately affected whether the "industry" is public or private, however, it is hard to press the argument far.

\section{E. Private, Foundation, and Federal Financial Support ${ }^{169}$}

Many state institutions are not exclusively public in the style of an agency like the Federal Communications Commission or a state corporation commission. Instead, they are partly financed by substantial private gifts and endowments ${ }^{170}$ and, like government enterprise, depend heavily upon consuner payments in the form of tuition. Significant federal financial aid and foundation support further complicate the matter. Such characteristics generally do not apply, however, to the centralized agencies and probably apply with less vigor to such institutions as community colleges. Should these characteristics, where they appear, affect structure?

There are two relevant aspects of extra-state financing. In one sense, it makes no difference that a public institution receives outside financial aid; the theoretical decision-making structure of the university is affected only to the extent that a decision to accept or reject aid must be made. The distribution of authority by delegation and subdelegation of power is conceptually separable from the funding of the enterprise in the same manner that an authorization bill and an appropriations bill are distinct legislative acts. Thus, in a theoretical sense, a university is like any other state-created enterprise which receives money froin other sources. Highway commissions and welfare agencies, for example, receive substantial federal aid, but this external fund-

169. See generally J. CoRson, supra note 18, at 143-65.

170. Approximately five percent of public college expenditures devoted to educational benefits derives from private support. Steinbach, Tax Reform and the Voluntary Support of Higher Education, 8 U. RICHMOND L. REv. 245, 247 (1974). 
ing gives them no special claim of uniqueness. Indeed, if the outside funding has any relevance, it may call for extra scrutiny to ensure that its influence does not seriously distort the decision-making structure:

Public organizations that operate on users fees, trust funds, or special funds derived from license fees or special taxes may enjoy a greater freedom from surveillance by superiors than those operating on general funds. They also tend to have low sensitivity to any interests but those of their special clientele. Clientele [read "students, alumni, and donors"] which pay special fees and taxes to suppont a public organization tend to view both it and its funds in a proprietary manner, subject solely to their scrutiny. Such surveillance as the organization in question experiences is likely to come from its special-involved relevant others, which may make it virtually a captive. ${ }^{171}$

As a practical matter, however, the severity of current budgetary limitations makes the substantial sums available from nonstate sources an attractive lightening of the burden on the public fisc. To continue drawing on these sources, umiversities must be hospitable to the aims and purposes of the givers, be they the federal government, wealthy alumni, or tuition-paying students. These sources will continue to be cultivated by institutions because their presence carries the collateral consequence of greater autononiy vis-á-vis the state. University officials find themselves in a posture of brokering demands from nuany sources but exclusively beholden to none.

Private and federal influences on state institutions deriving from financial input ${ }^{172}$ therefore call for enough flexibility in the legislative drafting that institutions can adjust to obtain some of the money offered, yet sufficient restrictions that the state's purpose is not thwarted. From a judicial perspective, doctrines of delegation and subdelegation are consistent with the realities of extra-state financial sources; for universities with explicit structure, final decisions on whether to take money with conditions attached should be made at the level which would otherwise be authorized to impose the conditions, in addition to the level in charge of financing. Ultimately, however, that is probably only a cosmetic solution for some important instances. Where the funding is significant enough, it will probably overwhelm other policy questions. After research departments have bcen built up and made dependent on federal funds, for exainple, and the federal government then attaches new conditions to its financing that entail academic policy changes in an area like admissions or appointments, it is unlikely that

171. G. WAMSLEY \& M. ZALD, supra note 138, at 42 (footnote omitted).

172. See generally C. KERR, suprá note 131 , at 58 , 
the units originally assigned decision-making responsibility over these academic matters will have any realistic policy-determining roles on the questions. The financial decision having been nade long since, the collateral policy changes inspired from outside are largely faits accompli. ${ }^{173}$ The imevitability of some outconies, lowever, does not call for coinplete elimination of the delegation and subdelegation restrictions. There will remain areas where the policy choice is not foreclosed. That private, foundation, and federal money contribute to a project does not lessen a state's legitimate concern for the administration of the resources it invests.

\section{F. Governance by Trustees}

Final governing authority in higher education is uniformly lodged in a group of individuals (trustees) who are generally unpaid and expected to convene for only a day or two several times a year to govern their institution or to order state-wide educational affairs. This is to be contrasted with other public agencies, where legislative or executive appointments to positions of final power are often full-time, fully paid positions. ${ }^{174}$ The implication of this distimction is clear-greater liberality in pernitting subdelegation from a university board of trustees ${ }^{175}$ or from the board of a coordinating commission ${ }^{176}$ should be allowed than in the case of other public agencies. The expectation of the legislature that trustees will meet infrequently countenances greater subdelegation to executive officers within the institution. ${ }^{177}$ Care must,

173. That is not to say that university personnel will necessarily comply.

174. It is recognized that there are some other exceptions--licensing boards, for example, frequently are not staffed by full-time administrative officers.

175. The AAUP position is:

The governing board of an institution of higher education, while maintaining a general overview, entrusts the conduct of administration to the administrative officers, the president and the deans, and the conduct of teaching and research to the faculty. The board should undertake appropriate self-limitation. American Association of University Professors et al., supra note 9, at 96.

176. Commentators recommend strong lay control for coordinating boards. See $\mathrm{L}$. GLenNy, R. BerdahL, D. Palola \& I. Paltridge, supra note 72, at 6.

177. Boards of directors of corporations are analogous. They are often composed partly of outsiders and meet only periodically. Despite their statutory duties or duties imposed by the articles of incorporation, courts have recognized that as a practical matter directors cannot govern all the affairs of the corporation and must be permitted to assign power to coinmittees of the board or to executive officers. See BalLENTINE on CORPORATIONS $\$ 46$, at 132 (1946):

[E]ven in the absence of express authority, an authority to delegate discretionary authority to committees, officers and agents must be implied from necessity and usage, for the directors cannot attend to all the current business operations of the corporation, and it is not customary for them to do so.

Accord, N. Lattin, The Law of Corporations $\$ 71$, at 243 (2d ed. 1971). Mr. Besse argues that corporate trustees are much better equipped for their duties than university 
however, be exercised in applying this concept. While the scope of subdelegation inust be broad, there obviously cannot be total abdication of authority. Trustees nnay not be expert in the day-to-day intricacies of educational administration, but their existence is clearly designed to preserve external control over the major directions of an institution. ${ }^{178}$

\section{SUMMARY AND APPLICATION}

\section{A. General Conclusions}

Public higher education is an agency of state government with many structural and functional similarities to other state administrative bodies. Application of similar legal principles concerning structure, then, might be expected. The law and learning on delegation and subdelegation constraints, however, are in some disarray. Moreover, administrative law specialists are increasimgly doubtful of the adequacy of holistic treatment. If any state administrative function is a likely candidate for special treatment it is public higher education. And even within higher education there are significant differences among individual institutions and between the class of individual institutions and that of centralized agencies. What general conclusions are available?

First, terms such as "umiversity," "higher education," and particularly the new category "post-secondary education" should not be consid-

trustees. Besse, $A$ Comparison of the University with the Corporation, in PERKINS RzPORT 107, 109. Moreover, courts and commentators have increasingly recognized soine implied powers deriving from an office, such as that of president of a corporation, to carry out certain functions:

[B]y force of what authority is usually delegated to the president, or assumed by him and not objected to by the board, there has been a growing tendency to imply the powers of a general inanager from the office alone .... That the authority is to be implied from the position ... removes the uncertainty of what must be proved and by whom and supports the general understanding of businessmen that the president is the executive head of the business and has the authority to carry on the business in its usual course. N. LATTIN, supra, $\S 75$, at 257-58; accord, H. HENN, HANDBOOK ON THE LAW OF CORPORATIONS $\$ 223$ ( $2 \mathrm{~d}$ ed. 1970).

178. See, e.g., J. DUFF \& R. BerdahI, University Government IN CANADA 13-14 (1966). Paradoxically, this structure also acts as a partial shield against political influence. Federal experience indicates, for example, that independent regulatory agencies, through the commission model, have a lower level of pobitical accountability than do single-administrator agencies. The source of a policy decision is more difficult to pinpoint when there are five or seven or eleven administrators participating in the final decision, rather than a single admmistrator. For a full criticism of the commission form and a laudatory view of the single-administrator form, see THE PRESIDENT's ADVISORY Council on Executive Organization, A New Regulatory Framiework: Report on Selected Independent Regulatory Agencies (1971) (The "Ash Council Report"). For criticism of this report and more merciful views of the commission form, see Robinson, On Reorganizing the Independent Regulatory Agencies, and Thomas, Politics, Structure and Personnel in Administrative Regulation, both in 2 RECOMMENDATIONS AND REPORTS OF THE ADMINISTRATIVE CONFERENCE OF THE UNITED STATES (1972): 
ered self-defining. Legislatures contemplating establishment of new institutions, reviewing the frameworks of old, or organizing centralized governing boards or coordinating agencies must work toward an articulation of the class of goals assigned to the institution or agency and the area of responsibility. Where legislatures succeed in articulating such parameters, courts should hold the institution or agency to its legislatively-assigned role. For example, when an institution is established with the explicit statutory goal of serving the state as a two-year, complete alternative to traditional higher education, its governing board, faculty, or administration should not be able to set admissions policies geared exclusively to selection of those students who will later transfer to a traditional four-year institution. Where legislatures fail to articulate the scope of an institution's or agency's functions, institutional or agency officials should make the attempt. Vague standards will undoubtedly continue to be the legislative norm for statewide agencies until greater consensus emerges on the aims and organization of public higher education. There is less cause for legislative vagneness $\mathrm{m}$ the establishment of individual mstitutions and, indeed, a strong argument against it is the avoidance of political pressure and interference. But seldom if ever would a delegation merit judicial overturning for lack of legislative standards. To be sure, important interests may be implicated-a private university's authority to grant degrees, for examplethat call for specific standards in administration. But, as Professor Davis suggests, these can be provided by the agency itself. The more difficult question arising from vague statutory language is whether a particular delegation occurred-whether an institution has ultimate control over the establishment of new programs, the centralized agency's right of review being limited to comment and criticism; or whether the agency has ultimate control, its failure to approve a particular program being fatal to the institution's efforts. Obviously, that is the sort of decision a legislature must make, for, in its absence, a court will have no basis upon which to allocate the power.

Second, so long as current methods of appoimting and paying trustees continue, legislatures should contemplate, and courts allow, a significant measure of subdelegation within a umiversity system or a centralized higher education agency. Obviously, there are limits. An agency with coordinating functions might be entitled to subdelegate functions to its administrative staff which it could not subdelegate to the institutions it is to coordinate. ${ }^{179}$ Before the power subdelegated

179. Cf. Hunnicutt v. Burge, 356 F. Supp. 1227, 1230 (M.D. Ga. 1973) (where a statewide board is under constitutional duty to desegregate its system, it is an abdication 
is recognized to be that of ostensible self-government, such as by students or faculty, careful attention should be paid to other interests that might be affected. Legislative specificity concerning subdelegation, however, should not be required. Often the factors producing the need for a subdelegation will not be amenable to legislative prediction. Moreover, courts must be sensitive to whether a subdelegation has occurred, looking as muoh to practice within and among institutions as to a paper record of explicit transfers of power. In all cases, however, review by the legislatively appointed delegatee should be preserved. It need not be exercised in each case, but it should be available. In the case of individual institutions, for example, the trustees-no matter how inexpert, rushed, and underpaid-have a role to occupy. Often they can act as an essential safety-valve by tempering some university programs and at the same time diverting some of the political attention away from university officers, faoulty, and students.

Third, state legislatures would do well to consider the role of extra-state funding froin sources such as foundations, the federal government, and alumni, and assess the resulting budgetary benefits against the loss of control the external funding presages. For judicial analysis, the presence of significant outside funding suggests closer scrutiny of structural requirements.

Beyond these few and limited general conclusions, the characteristics of publio higher education counsel individualistic treatment. History, the needs of academic freedom, the political community-like quality of a university -all may indioate recognition of wide or narrow authority at various levels under various circumstances.

\section{B. A Case in Point}

A concrete example of a university delegation/subdelegation problem (the honor system problen outlined at the beginning of the Article) concludes the analysis. This problem will be considered in terms of the University of Virginia honor system. The challenge confronting this lionor system is largely a subdelegation problem: is the governing board entitled to remit expulsion power to students?

(1) Recognition of the Subdelegation. First, though, this problein is also a useful example of the question, did the subdelegation occur? Perusal of official University documents reveals no explicit subdelegation of power to the Honor Committee. Instead, one finds in the Board of Visitors Manual under the heading "Powers and Duties"

of its legal responsibility to adopt simply an open-door policy and to delegate its implementation to individual institutions), 
of the Board the following: "[T]he preservation of the ideas and traditions of the university and particularly encouragement of the maintenance of the Honor System by the Student Body." "Powers and Duties" of the President, one finds: "[H]] shall use his particular efforts to preserve and foster the Honor System."181 Arguably, then, the Board has not had occasion to subdelegate any power at all, or, the construction most students seem to prefer, the power is inherently that of the student body and the Board has agreed not to interfere. The final reference to the honor system in the Manual seems to bear this out: "The Board at its discretion shall hear such appeals as are provided for in the University regulations except that in no event shall the Board entertain an appeal from a decision of the Honor Committee." 182 Obviously, this tidy explanation does not satisfy the legal niceties: a group of private citizens may not take it upon themselves to decide independently who will be excluded from governmental benefits. And the mechanics of expulsion reveal the undeniable fact that the Umiversity administration ultimately closes the student's file and prevents him from re-registering. ${ }^{183}$ But it is unnecessary to pierce the myth (whether or not one accepts the value of its premises) by requiring an explicit Board statement that the power belongs to it and has been subdelegated only at its pleasure. The references quoted above are sufficient, in the view of this observer, to establish de facto subdelegation. The only arguments for requiring a more explicit assigument of power would be: (1) that it would require the Board to confront the question directly and not lose its power unaware; (2) that it would provide adequate notice to those affected by the system; (3) that it would provide notice to the legislature that the Board had indeed delegated such power so that the legislature might react if such a subdelegation were beyond the Board's power. Popular and, to some extent, written history indicates that the honor system has been functioning since about 1842, and in its current status at least during this century. ${ }^{184}$ Given this long history and the publicity the honor

180. MaNual OF THE BoARd OF Visitors OF THE UNIVERSITY OF VIRGINIA $\S 2.4(1)$ (1966).

181. Id. $\$ 4.22(11)$. The author has learned that entries in the official minutes of the Board contain nothing more explicit on the question of subdelegation.

182. Id. $\$ 5.1$.

183. Cf. Andrews v. Knowlton, 509 F.2d 898 (2d Cir. 1975) (finding cadet honor committee clearly a part of process by which the United States Military Academy achieves separation and therefore a part of government process).

184. See, e.g., T. Taylor, A History of the Honor System at the University of Virginia to 1956 (unpublished manuscript on file at the offices of Duke Law Journal, Durham, North .Carolina). 
system enjoys at the University and within Virginia, none of the arguments for an explicit subdelegation is supportable. To require a formal action would indeed impose unnecessary bureaucratic demands on an acadernic commumity. Obviously, if the subdelegation were ill-known and had occurred only recently, a different conclusion might be appropriate.

(2) Permissibility of the Subdelegation. On the primary issue, whether the subdelegation was permissible, there are only two relevant statutory provisions: (1) for the University of Virginia specifically, the Board of Visitors

may appoint a comptroller and proctor, and employ any other agents or servants, regulate the government and discipline of the students, and the renting of the rooms and dormitories, and, generally, in respect to the government and management of the Uriversity, make such regulations as they may deem expedient, not being contrary to law; $;^{185}$

and (2) for Boards of Visitors generally in Virginia, the power is as follows:

[T] he board of visitors . . . shall have the power: (1) . . . to establish rules and regulations for the conduct of students while attending such institution; and to establish rules and regulations for the dismissal of students who fail or refuse to abide by such regulations. ${ }^{186}$

Pursuing traditional subdelegation analysis, one finds no legislative history and no evidence of a Virginia practice of explicitly according or denying authority to subdelegate. The statutory delegation to make rules and regulations weighs in favor of subdelegation. Subdelegation to a group of students, however, is distinct from subdelegation to officials within an admimistrative hierarchy. Under traditional administrative law analysis, it is equivalent to a subdelegation by the agenoy to the group supposed to be regulated, a somewhat suspicious transaction. ${ }^{187}$ The interests at stake - a subsidized higher education at a good school and the preservation of the student's reputation-are obviously important. Arguably, the assignees of the power-other students-rank lower on a responsibility scale than would administrative officials or even faculty members. Disoretion is obviously involved: when, for example, is a misappropriation a theft that merits expulsion rather than a prank that merits internal discipline? Finally, the Board insists that it will not review a decision of the Honor Committee. Un-

185. VA. CODE ANN. \$ 23-9.2:3 (Repl. vol. 1973).

186. Id. \& 26-76.

187. See Carter v. Carter Coal, 298 U.S. 238 (1936). But cf. United States v. Rock Royal Co-operative, Inc., 307 U.S. 533 (1939). 
der conventional analysis, then, a judgment on the permissibility of the subdelegation is at best mixed and probably leans against it. To the extent the "functional" approach has any content and to the extent Virginia courts would adopt it, the University can of course argue that the assignment of final responsibility to students on these matters is essential to the educational program the Board has been assigned to carry out and therefore should be sustained. All in all, however, this is a somewhat shaky case under a conventional subdelegation analysis.

What result if the specific characteristics of higher education are considered? (1) Trustee characteristics, we have argued, suggest a presumption that subdelegation be allowed. That argument, however, encourages subdelegation to others with superior knowledge of educational matters (assessment of academic credentials, for example, assigned to a committee of persons from that field). The part-time nature of trustee governance will not alone sustam a subdelegation to a student group. (2) Extra-state funding, while important at the University of Virginia, would appear to have no special bearing on this problem, except in the sense of alumni preference for things as they have always been. (3) In terms of history, the author is unaware that honor system-type discipline was such an essential part of public higher education when the University was established in 1819 that the subdelegation can be said to have been contemplated. On the other hand, in a series of subsequent statutory alterations, the legislature has not chosen to challenge the subdelegation. Thus, while history carries no clear message, it does fall on the side of permissibility. (4) The interest in flexibility that academic freedom implies has already been addressed. ${ }^{188}$ (5) The enterprise quality of state higher education seems virtually irrelevant to the analysis in this context-social and academic regulations under which matriculants spend four or more years of their lives. The issues involved here are closely akin to governmental regulations of private activity. (6) The "community" argument, however, is pertinent. The University of Virginia has a substantial on-campus enrollment and the honor systen deals with social and academic mores that are legitimately the concern of enrolled students. The community aspect therefore suggests a strong decision-making role for students. On the other hand, the only available sanction for breach of the Honor Code is expulsion. While on-campus and dormitory mores may be a proper concern of students, exclusion from public benefits is not. The state, grantor of the subsidy, has an important interest in the standards under which its investment in young lives will be terminated. Fimal 
and exclusive power lodged in the students seems improper on this reasoning. Some role on the part of the board, the agency initially assigned the power and having direct responsibility to the legislature, is necessary in the establishment and application of standards for exclusion. ${ }^{180}$

This question of standards reveals that, as is often the case, a delegation problem lies submerged in the subdelegation issue. Are the standards for exercising the power of exclusion sufficiently specific? Obviously, the legislature has provided no standards, a fatal flaw under traditional delegation analysis. What is more, the board and administration (the delegatees) have likewise provided no standards, a problem under the newer Davis approach. ${ }^{190}$ Indeed, the very theory of the honor system is that no one but the students should have a role in setting the standards. Will this suffice? If the analysis is solely one of due process, the developer of the standards should not niatter so long as they are developed, published, and applied fairly and responsibly. But the concerns of delegation and subdelegation require the state-apponited agents-the board and its official delegatees, the university adininistration-to maintain at least a reviewing responsibility. ${ }^{191}$ That is, a refusal to review by the administration or board should be based, not on a lack of power, but upon agreement with the Honor Committee's disposition. A total abdication of responsibility for Honor Coinmittee resolutions, like that suggested by the Board of Visitors Manual, is at odds with even a broad reading of the power to delegate and subdelegate.

My conclusion then, is that the University's honor system should be sustained, with the one qualification that the administration's and board's purported incapacity to review the system's substantive rules and procedures be discarded. That is not to say that every rule and

189. Some would argue that without some form of de novo review, a delegation to students to find facts is an impermissible delegation violating precepts of fundamental fairness (due process) when such important interests are at stake and the issues so often hinge on credibility. Given the reputed experience of Virginia's honor systein and given the fact that students now reach majority at age eighteen, however, it is hard to conclude that students qua students must be considered unqualified for suck a subdelegation on grounds of immaturity. Moreover, there is less self-interest involved than $\mathrm{m}$ other commonly accepted collegiate decision-making processes-for example, faeulty selection or tenure decisions respecting their colleagues. If it is the absence of lawyers that is troubling in these trial-like proceedings, then the objection is not to student power at all, for the same objection could be raised if administrators were making the decisions. Thus, the author concludes that there is no inherent prohibition against a student decision-making role.

190. See notes $36-40$ supra and accompanying text.

191. Cf. United Stațes v, Roçk Royal Co-operative, Inc., 307 U.S. 533, 576 (1939). 
every decision must be actively considered by the Board. Mature and proper dispositions by the honor system, as has often been characteristic, may obviate the necessity for active review. But responsibility for what happens is, ultimately, the Board's. The route of appeal must remain open.

The University of Virginia honor system problem is but one exainple of the many potential delegation/subdelegation problems lurking within the context of public higher education. A major thesis advanced by this Article has been that their resolution demands careful consideration of a wide range of complex factors associated with university governance structures. It deserves emphasis that the utility of the delegation doctrine in this context is to trace lines of accountability. The propriety of a delegation or subdelegation should be judged not only by the necessity for administrative regulation but also by the need for adequate safeguards. The adequacy of safeguards depends, in turn, upon the interests affected, the severity of the sanction, and the opportunity for ineaningful review. ${ }^{192}$

192. See $1 \mathrm{~K}$. DAvIS $\$ 2.15$. 


$$
\text { - }
$$

